\title{
Self-assembled pyridine-dipyrrolate cages
}

\author{
Huacheng Zhang, ${ }^{\dagger}$ Juhoon Lee, ${ }^{\dagger}$ Aaron D. Lammer ${ }^{\dagger}$ Xiaodong Chi, ${ }^{\dagger}$ James T. Brewster, ${ }^{\dagger}$ \\ Vincent M. Lynch, ${ }^{\dagger}$ Hao Li, ${ }^{\dagger}$ Zhan Zhang $^{\dagger, \S}$ and Jonathan L. Sessler ${ }^{*}, \dagger, \S$ \\ $\dagger$ Department of Chemistry, The University of Texas at Austin, 105 East 24th Street-Stop A5300, \\ Austin, Texas 78712-1224, United States \\ †Department of Chemistry, Zhejiang University, Hangzhou 310027, China \\ §Institute for Supramolecular and Catalytic Chemistry, Shanghai University, Shanghai 200444 China
}

\section{Supporting Information}

\author{
I. Synthetic Experimental \\ II. UV and Fluorescence Analyses \\ III. Morphology Studies \\ IV. Supplementary Figures \\ V. X-Ray Experimental \\ VI. References
}




\section{Synthetic Experimental}

\section{Materials and Instruments}

All reagents and solvents were purchased from commercial suppliers and used without further purification. Analytical thin-layer chromatography (TLC) was performed using commercial pre-coated silica gel plates containing a fluorescent indicator. Column chromatography was carried out using silica gel $(0.040-0.063 \mathrm{~mm})$. Low resolution mass spectra (MS) and high-resolution mass spectra (HRMS) were measured using an Ion Spec Fourier Transform mass spectrometer (9.4 T). Proton and ${ }^{13} \mathrm{C}$ NMR spectra were recorded using a Varian 400 spectrometer and chemical shifts are reported in ppm using TMS as an internal reference standard.

\section{Synthesis and Characterization}

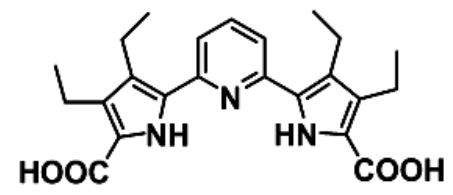

1

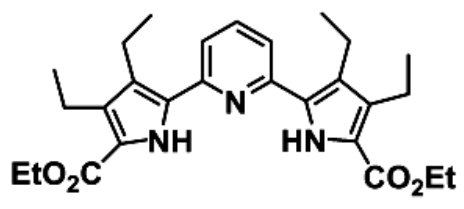

3

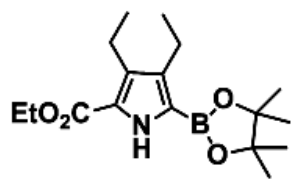

2

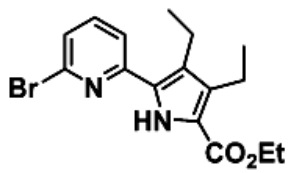

4

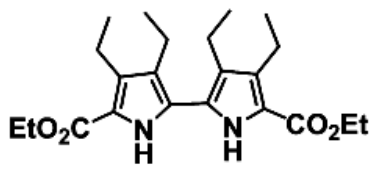

5

Scheme S1 Structures of compounds 1 5

General method for the synthesis of compounds 3 5: Compound 2 was synthesized according to a literature procedure. ${ }^{\mathrm{S} 1}$ Compound $\mathbf{3}$ was synthesized through a palladium(II) acetate-catalyzed Suzuki-Miyaura cross-coupling reaction using 2,6-dibromopyridine purchased commercially and compound 2 as the reaction partners in a molar ratio of 1:2.4 in accord with our previously reported protocol. $^{\mathrm{S} 2}$ Column chromatographic purification of the crude product over silica gel using dichloromethane/methanol (50/1) as the eluent afforded analytically pure product 3 in the form of yellow solid with a yield of $85 \%$. The colorless compound $\mathbf{4}$ and the orange product $\mathbf{5}$ were obtained under these reaction conditions, albeit only in trace yields. If the molar ratio of 2,6-dibromopyridine and compound $\mathbf{2}$ in the reaction mixture was adjusted to 3:1, compound $\mathbf{4}$ could be obtained in a yield of $57 \%$.

2: $81 \%$ yield, red oil. ${ }^{1} \mathrm{H}$ NMR (400 MHz, $\left.\mathrm{CDCl}_{3}\right): \delta=9.10(\mathrm{~s}, 1.13 \mathrm{H}), 4.33-4.27(\mathrm{~m}, 2.11 \mathrm{H}), 2.72(\mathrm{q}$, 
$J=8,2.00 \mathrm{H}), 2.62(\mathrm{q}, J=8,1.94 \mathrm{H}), 1.34(\mathrm{t}, J=4,2.84 \mathrm{H}), 1.29(\mathrm{~s}, 9.72 \mathrm{H}), 1.12(\mathrm{q}, J=4,5.50 \mathrm{H})$. ESI-MS: $322.2[M+\mathrm{H}]^{+}$.

3: $85 \%$ yield, yellow solid. ${ }^{1} \mathrm{H}$ NMR (400 MHz, $\left.\mathrm{Me}_{2} \mathrm{CO}-d_{6}\right): \delta=7.90$ (q, $J=8,1.40 \mathrm{H}$ ), 7.64 (d, $J=4$, $2.76 \mathrm{H}), 4.31(\mathrm{q}, J=4,4.00 \mathrm{H}), 2.90-2.79(\mathrm{~m}, 14.17 \mathrm{H}), 1.35(\mathrm{t}, J=8,5.52 \mathrm{H}), 1.27(\mathrm{t}, J=8,7.15 \mathrm{H})$, $1.17(\mathrm{t}, J=8,5.70 \mathrm{H})$. ESI-MS: $466.2[M+\mathrm{H}]^{+}$.

4: $57 \%$ yield, colorless crystalline material. ${ }^{1} \mathrm{H}$ NMR (400 $\left.\mathrm{MHz}, \mathrm{CDCl}_{3}\right): \delta=9.80(\mathrm{~s}, 0.89 \mathrm{H})$, 7.54-7.46 (m, 2.00H), 7.28-7.24 (m, 1.31H), 4.35 (q, $J=8,1.94 \mathrm{H}), 2.79-2.68(\mathrm{~m}, 3.96 \mathrm{H}), 1.37(\mathrm{t}, J=$ 8, 3.03H), 1.21-1.14 (m, 6.04H). ${ }^{13} \mathrm{C}$ NMR (100 MHz, $\left.\mathrm{CDCl}_{3}\right): \delta=161.1,150.7,141.7,138.9,134.3$, $128.5,126.2,125.2,119.5,118.2,60.1,53.3,17.9,15.9,15.2,14.4$. HR-MS (ESI): $\mathrm{C}_{16} \mathrm{H}_{19} \mathrm{BrN}_{2} \mathrm{O}_{10}$ calcd for $m / z=373.0522$, found $m / z=373.0524[M+\mathrm{Na}]^{+}$.

5: orange solid. ${ }^{1} \mathrm{H}$ NMR (400 MHz, $\mathrm{CDCl}_{3}$ ): $\delta=8.99$ (s, $0.95 \mathrm{H}$ ), 4.26 (q, $J=8,2.00 \mathrm{H}$ ), 2.76 (q, $J=4$, $2.06 \mathrm{H}), 2.44$ (q, $J=8,2.20 \mathrm{H}), 1.32(\mathrm{t}, J=8,3.10 \mathrm{H}), 1.17(\mathrm{t}, J=8,3.35 \mathrm{H}), 1.04(\mathrm{t}, J=8,2.97 \mathrm{H}) .{ }^{13} \mathrm{C}$ NMR $\left(100 \mathrm{MHz}, \mathrm{CDCl}_{3}\right): \delta=133.3,125.9,123.9,118.6,59.9,18.3,17.5,16.1,15.7,14.4$. HR-MS (ESI): $\mathrm{C}_{22} \mathrm{H}_{32} \mathrm{~N}_{2} \mathrm{O}_{4}$ calcd for $m / z=411.2254$, found $m / z=411.2258[M+\mathrm{Na}]^{+}$.

General method for the synthesis of compound 1: Compound $3(1.2 \mathrm{~g}, 2.5 \mathrm{mmol})$ was dissolved in 50 $\mathrm{mL}$ EtOH. Aqueous $10 \% \mathrm{NaOH}(7 \mathrm{~mL})$ was then added under an $\mathrm{N}_{2}$ atmosphere. The resulting reaction mixture was stirred and heated to $85{ }^{\circ} \mathrm{C}$ for 6 hour. The reaction flask was allowed to cool to room temperature. At this juncture, $10 \% \mathrm{HCl}_{\text {aq }}$ was used to adjust the $\mathrm{pH}$ value of the solution to neutrality, at which point a white precipitates appeared. After collecting and drying these precipitates under an $\mathrm{N}_{2}$ atmosphere, the desired product ( $0.93 \mathrm{~g}$; $88 \%$ yield) was obtained in the form of a white powder.

1: $88 \%$ yield, white powder. ${ }^{1} \mathrm{H}$ NMR (400 MHz, $\left.\left(\mathrm{CD}_{3}\right)_{2} \mathrm{SO}\right): \delta=12.45$ (br s, $\left.1.47 \mathrm{H}\right), 11.54(\mathrm{~s}, 1.97 \mathrm{H})$, $7.88(\mathrm{t}, J=8,1.00 \mathrm{H}), 7.51(\mathrm{~d}, J=4,1.93 \mathrm{H}), 2.76-2.68(\mathrm{~m}, 8.10 \mathrm{H}), 1.18(\mathrm{t}, J=8,6.02 \mathrm{H}), 1.12(\mathrm{t}, J=8$, $6.08 \mathrm{H}) .{ }^{13} \mathrm{C}$ NMR $\left(100 \mathrm{MHz},\left(\mathrm{CD}_{3}\right)_{2} \mathrm{SO}\right): \delta=162.8,150.0,133.2,131.1,125.0,119.7,118.7,109.9$, 17.9, 17.8, 16.6, 16.2. HR-MS (ESI): $\mathrm{C}_{23} \mathrm{H}_{27} \mathrm{~N}_{3} \mathrm{O}_{4}$ calcd for $m / z=410.2074$, found $m / z=410.2072[\mathrm{M}$ $+\mathrm{H}]^{+}$

\section{UV and Fluorescence Analyses}

UV-vis spectra were measured on a Varian Cary 5000 spectrophotometer. Fluorescence spectra were recorded on a Triax 320 fluorescence spectrometer. Samples for UV and fluorescent spectral analysis were prepared in a mixed solvent consisting of DMF and $\mathrm{MeOH}(1: 5, \mathrm{v} / \mathrm{v})$. For the UV-vis studies, the concentration of compound 1 was $10^{-5} \mathrm{M}$ and 1 equivalent of either $\mathrm{Zn}(\mathrm{acac})_{2}$ or $\mathrm{Zn}(\mathrm{OAc})_{2}$ was used. For the fluorescent studies, this stock sample solution was further diluted to $10^{-6} \mathrm{M}$. The mixed solutions were sonicated as needed until there was no evidence of residual insoluble material.

Job's continuous variation method was employed to obtain insights into the stoichiometry of the complexes formed from compound $\mathbf{1}$ and the $\mathrm{Zn}$ (II) cation. Analyses were carried out via fluorescence 
titrations over a concentration range of $10^{-5}$ to $10^{-6} \mathrm{M}$. All sample solutions for these investigations were freshly prepared by diluting stock solutions. A set of working solutions was then obtained by mixing $V_{l} \mathrm{~mL}$ of the stock solution of compound 1 with $\left(V_{t}-V_{l}\right) \mathrm{mL}$ of the stock $\mathrm{Zn}^{2+}$ solution, where $V_{t}$ is a fixed total volume and $V_{l}$ was varied from 0 to $10 \mathrm{~mL}\left(0 \leq V_{l} \leq V_{t}\right)$.

\section{Morphological Studies}

The samples for SEM analyses were prepared by placing a droplet of a yellowish sample solution consisting of compound 1 and $\mathrm{Zn}(\mathrm{OAc})_{2}$ in a mixture of DMF and $\mathrm{MeOH}(1: 5, \mathrm{v} / \mathrm{v})$ onto a copper grid (200 mesh, coated with carbon film), followed by vacuum drying. SEM images were obtained on a Hitachi S5500 STEM instrument (accelerating voltage $=10.0 \mathrm{kV}$, emission current $=20 \mu \mathrm{A}$ ). Dynamic light scattering (DLS) measurements were carried out at $298 \mathrm{~K}$ using a Malvern Instruments Ltd Zetasizer Nano ZS instrument equipped with a $633 \mathrm{~nm}$ "red" laser. The mean hydrodynamic size was calculated using the Zetasizer software. All solvents were filtered through a $0.2 \mu \mathrm{m}$ filter before use.

\section{Supplementary Figures}

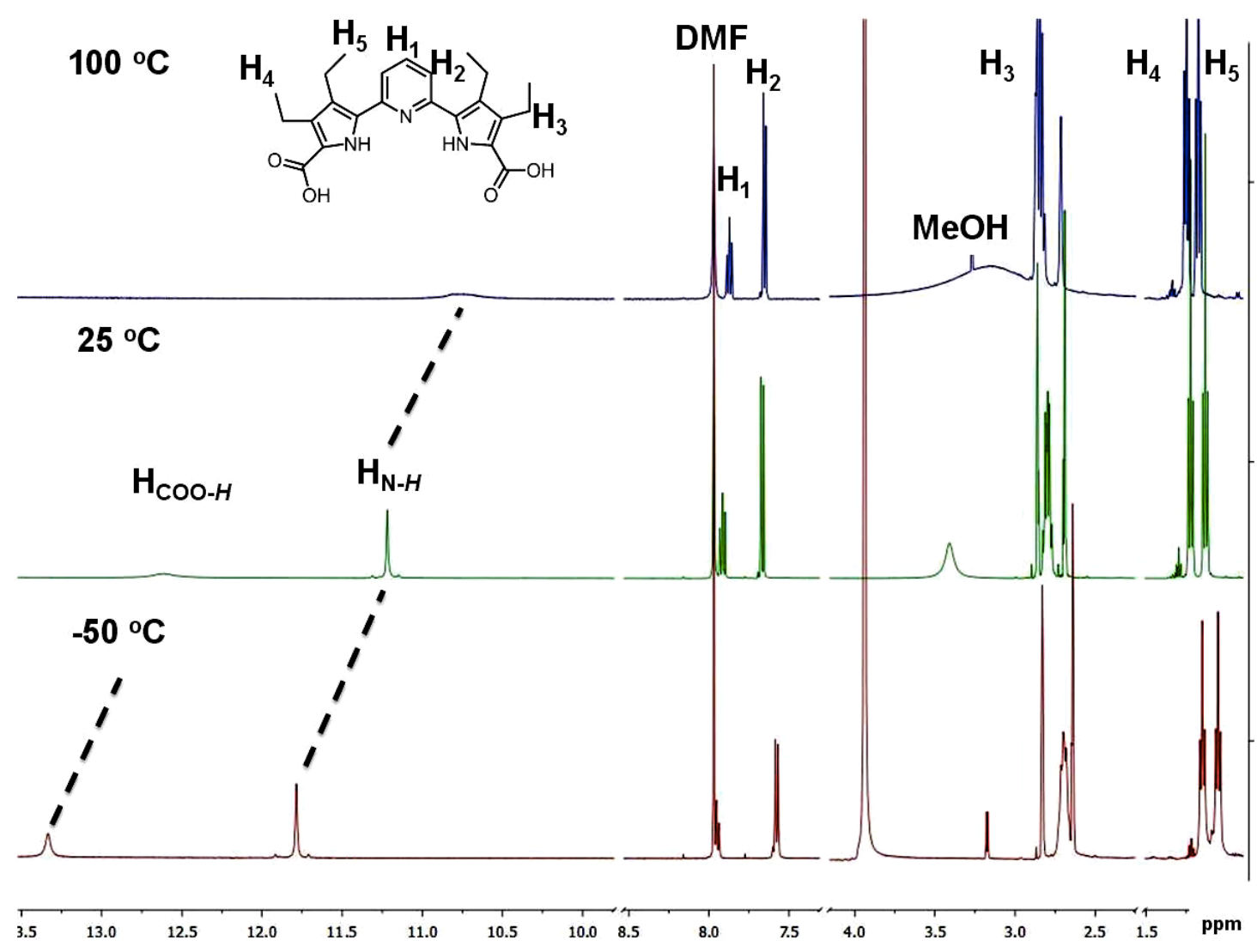

Figure S1. VT ${ }^{1} \mathrm{H}$ NMR spectra ( $400 \mathrm{MHz}, 10 \mathrm{mM}$, DMF- $d_{7}$ ) of compound 1 at variable temperatures of $-50{ }^{\circ} \mathrm{C}, 25{ }^{\circ} \mathrm{C}$, and $100{ }^{\circ} \mathrm{C}$ from bottom to top. 


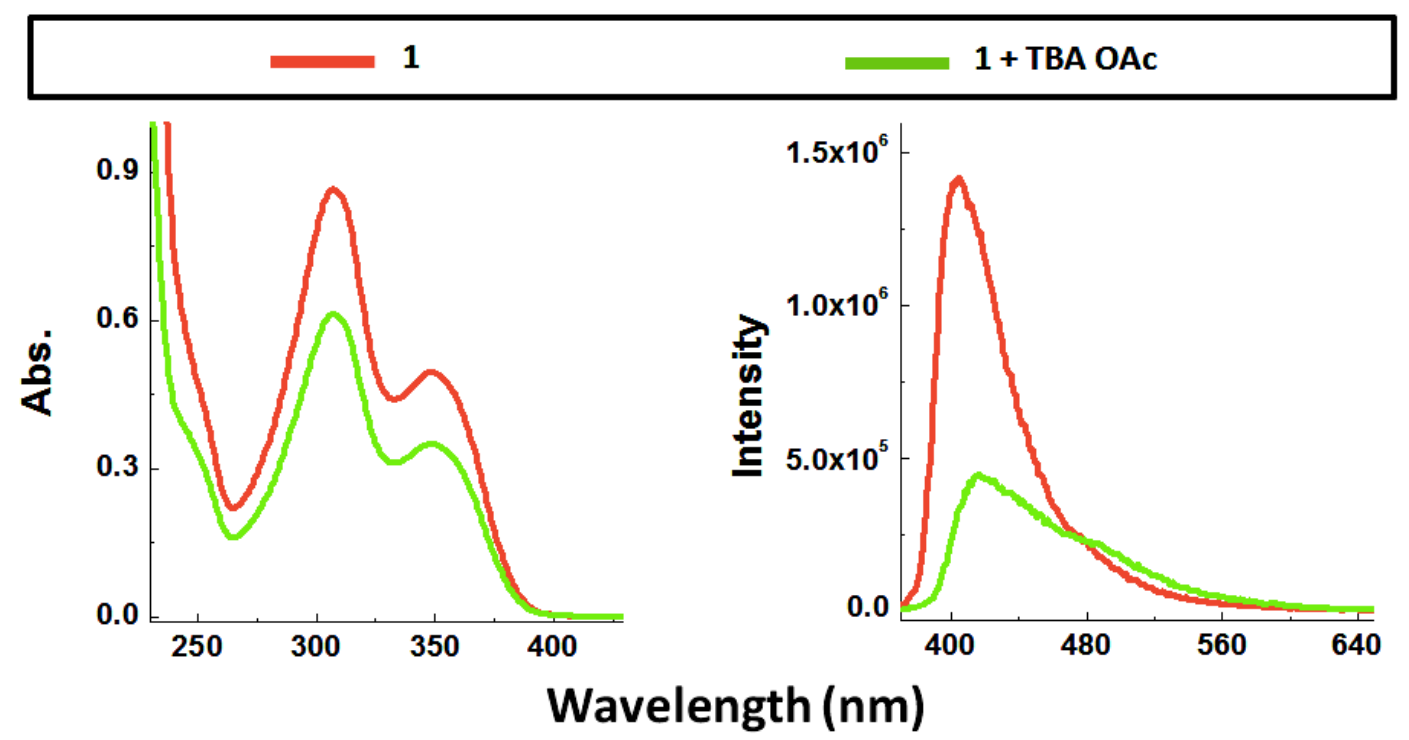

Figure S2. Changes in the UV-vis $\left([\mathbf{1}]=10^{-5} \mathrm{M}\right.$, left) and fluorescent emission spectra (excited at 365 $\mathrm{nm}$, right) of a sample solution of $\mathbf{1}\left([\mathbf{1}]=10^{-6} \mathrm{M}\right.$, red line) in DMF:MeOH $(1: 5, \mathrm{v} / \mathrm{v})$ observed upon the addition of 1 equivalent of TBA·OAc (green line).

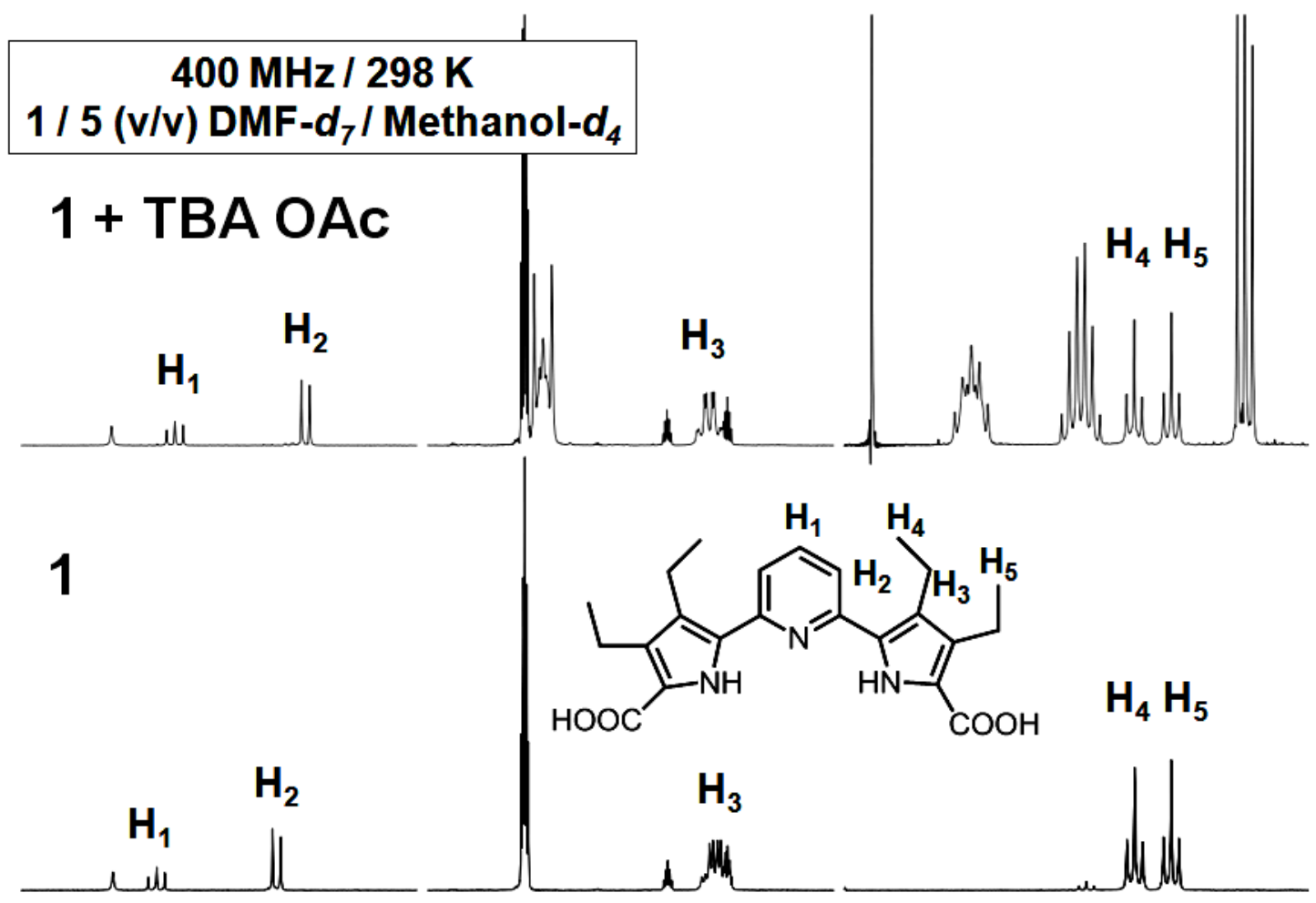

$\begin{array}{lllllllllllllllllllllllllllllllll}1.2 & 8.1 & 8.0 & 7.9 & 7.8 & 7.7 & 7.6 & 7.5 & 7.4 & 7.3 & 3.5 & 3.4 & 3.3 & 3.2 & 3.1 & 3.0 & 2.9 & 2.8 & 2.7 & 2.6 & 1.9 & 1.8 & 1.7 & 1.6 & 1.5 & 1.4 & 1.3 & 1.2 & 1.1 & \mathrm{ppm}\end{array}$

Figure S3. ${ }^{1} \mathrm{H}$ NMR spectra $\left(400 \mathrm{MHz}\right.$, room temperature) of compound $1\left(10^{-2} \mathrm{M}\right)$ with $(1: 1 \mathrm{molar}$ ratio, up) and without (bottom) TBA.OAc recorded in a mixed solvent system consisting of $\mathrm{N}, \mathrm{N}$-dimethylformamide- $d_{7}\left(\mathrm{DMF}-d_{7}\right)$ and methanol- $d_{4}(1: 5, \mathrm{v} / \mathrm{v})$. 


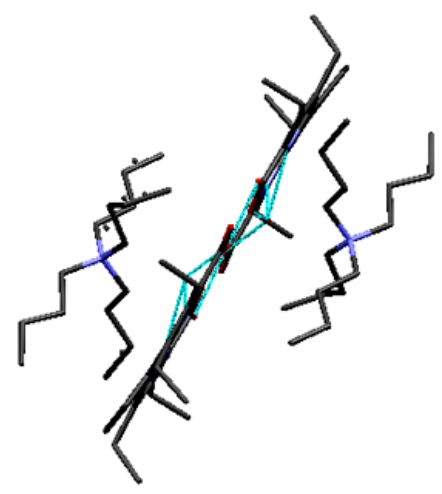

Axis a

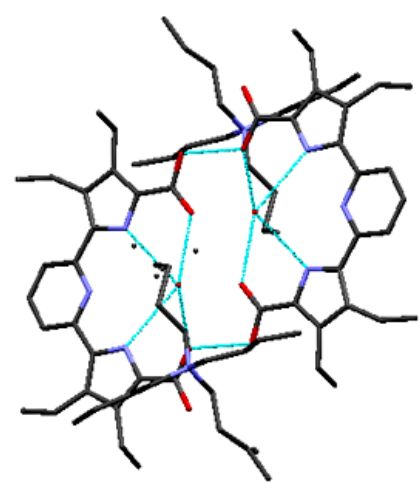

Axis b

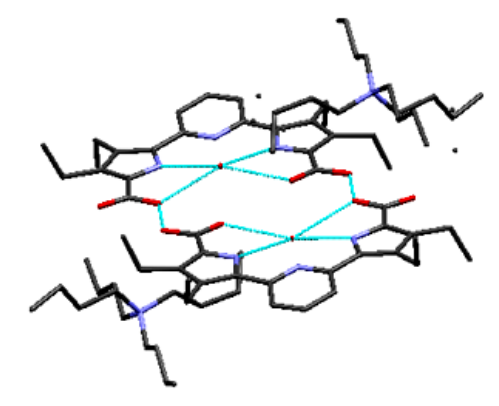

Axis c

Figure S4. Hydrogen bonds (blue lines) inferred from the structural parameters of the crystal structure of the dimer formed from 1. Color: $\mathrm{C}$ gray, $\mathrm{N}$ blue, $\mathrm{O}$ red. The hydrogen atoms were omitted for clarity.

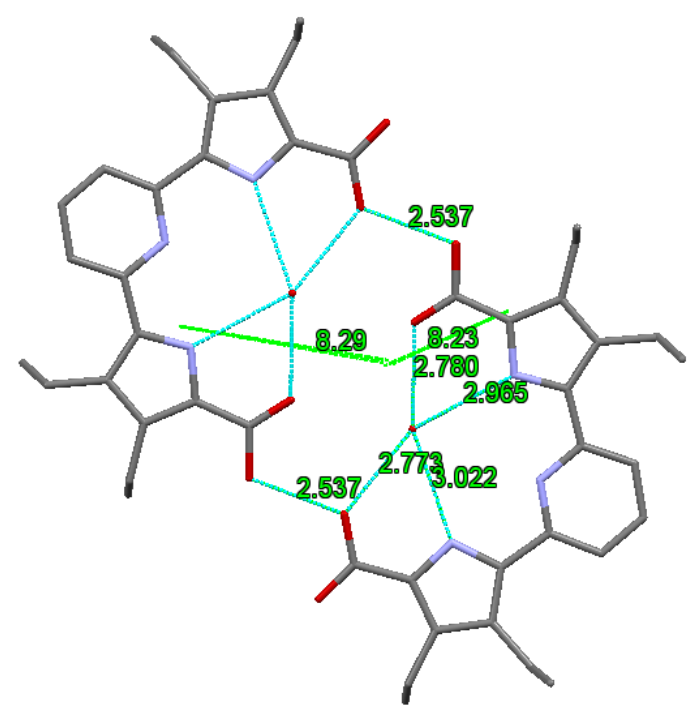

Figure S5. Hydrogen bonds (blue lines) and NCCN dihedral angles $\left(8.23\right.$ and $\left.8.29^{\circ}\right)$ inferred from the metric parameters of the crystal structure of the dimer of $\mathbf{1}$. Other values indicate distances between two nearby nitrogen and oxygen atoms. Color: $\mathrm{C}$ gray, $\mathrm{N}$ blue, $\mathrm{O}$ red. The hydrogen atoms and the $\mathrm{TBA}^{+}$cation are omitted for clarity. 

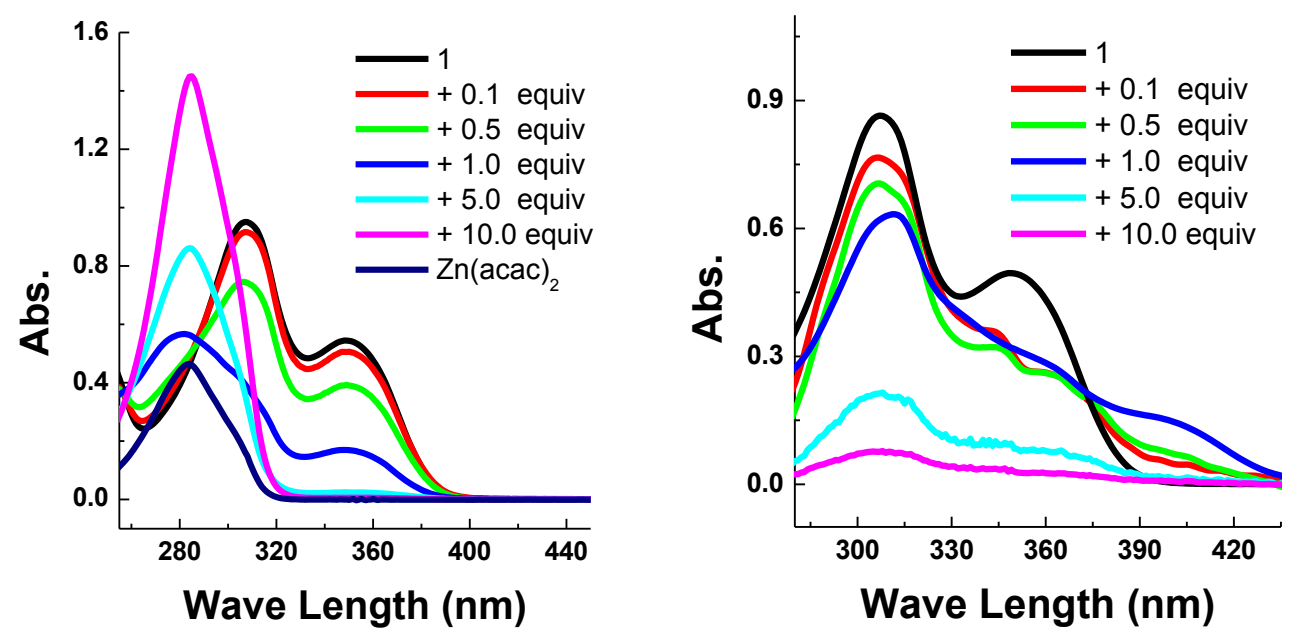

Figure S6. Changes in the UV-Vis spectrum of $\mathbf{1}\left(10^{-5} \mathrm{M}\right)$ in DMF-MeOH $(1 / 5, \mathrm{v} / \mathrm{v})$ as the ratio of $\mathrm{Zn}(\mathrm{acac})_{2}$ (left) and $\mathrm{Zn}(\mathrm{OAc})_{2}$ (right) is varied.
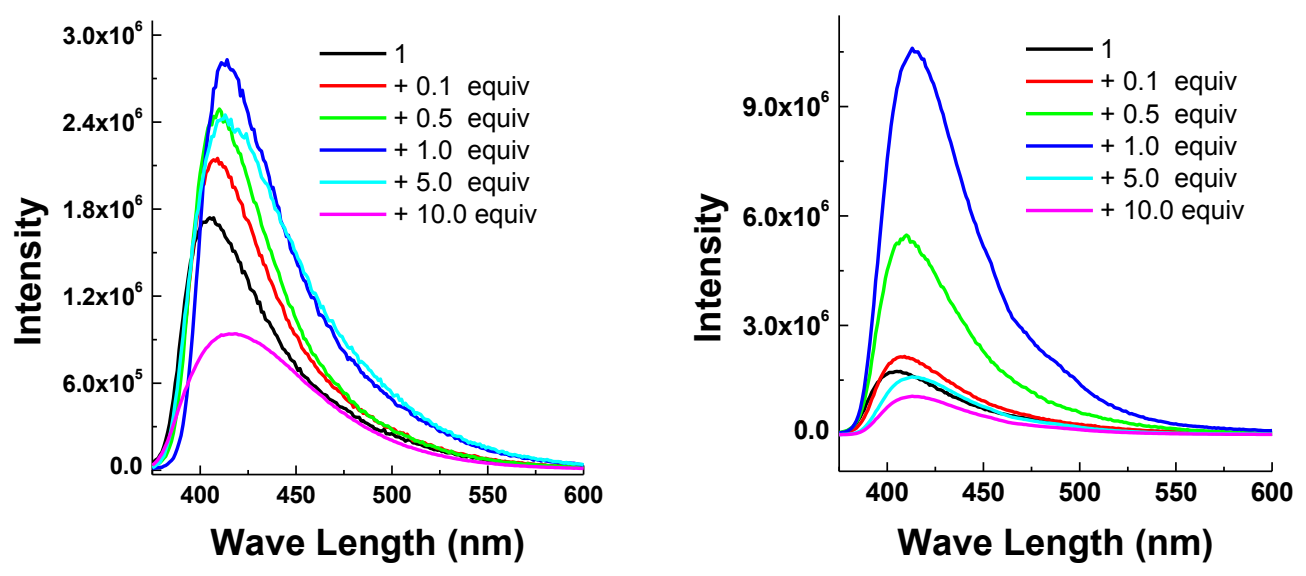

Figure S7. Changes in fluorescent emission spectra of compound $1\left(10^{-6} \mathrm{M}\right.$, excited at $\left.365 \mathrm{~nm}\right)$ in $\mathrm{DMF}-\mathrm{MeOH}(1 / 5, \mathrm{v} / \mathrm{v})$ as the ratio of $\mathrm{Zn}(\mathrm{acac})_{2}$ (left) and $\mathrm{Zn}(\mathrm{OAc})_{2}$ (right) is varied.

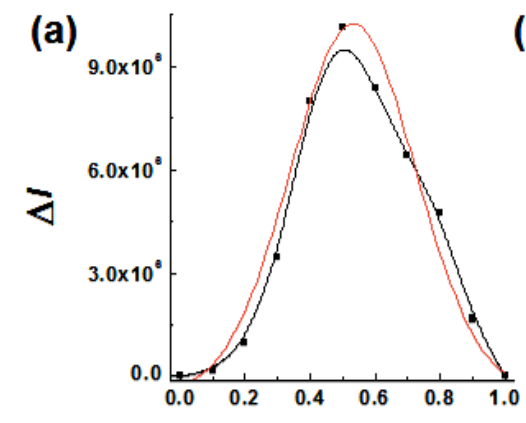

(b) $8.0 \times 1$

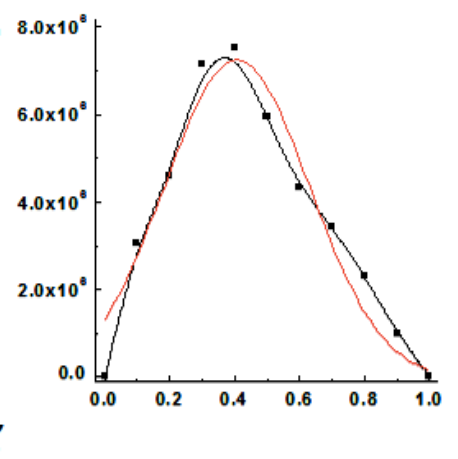

Figure S8. Job's plots constructed using the fluorescence emission maximum corresponding to the 
interaction of compound 1 with $\mathrm{Zn}(\mathrm{acac})_{2}(\mathrm{a}, 410 \mathrm{~nm})$ or $\mathrm{Zn}(\mathrm{OAc})_{2}(\mathrm{~b}, 432 \mathrm{~nm})$ in a 1:5 (v/v) mixed solvent mixture consisting of DMF and MeOH. $X=[\mathbf{1}] /\left([\mathbf{1}]+\left[\mathrm{Zn}^{2+}\right]\right) .[1]=10^{-5} \mathrm{M}$. Excited at $365 \mathrm{~nm}$. Red line, fit to a Gaussian distribution.

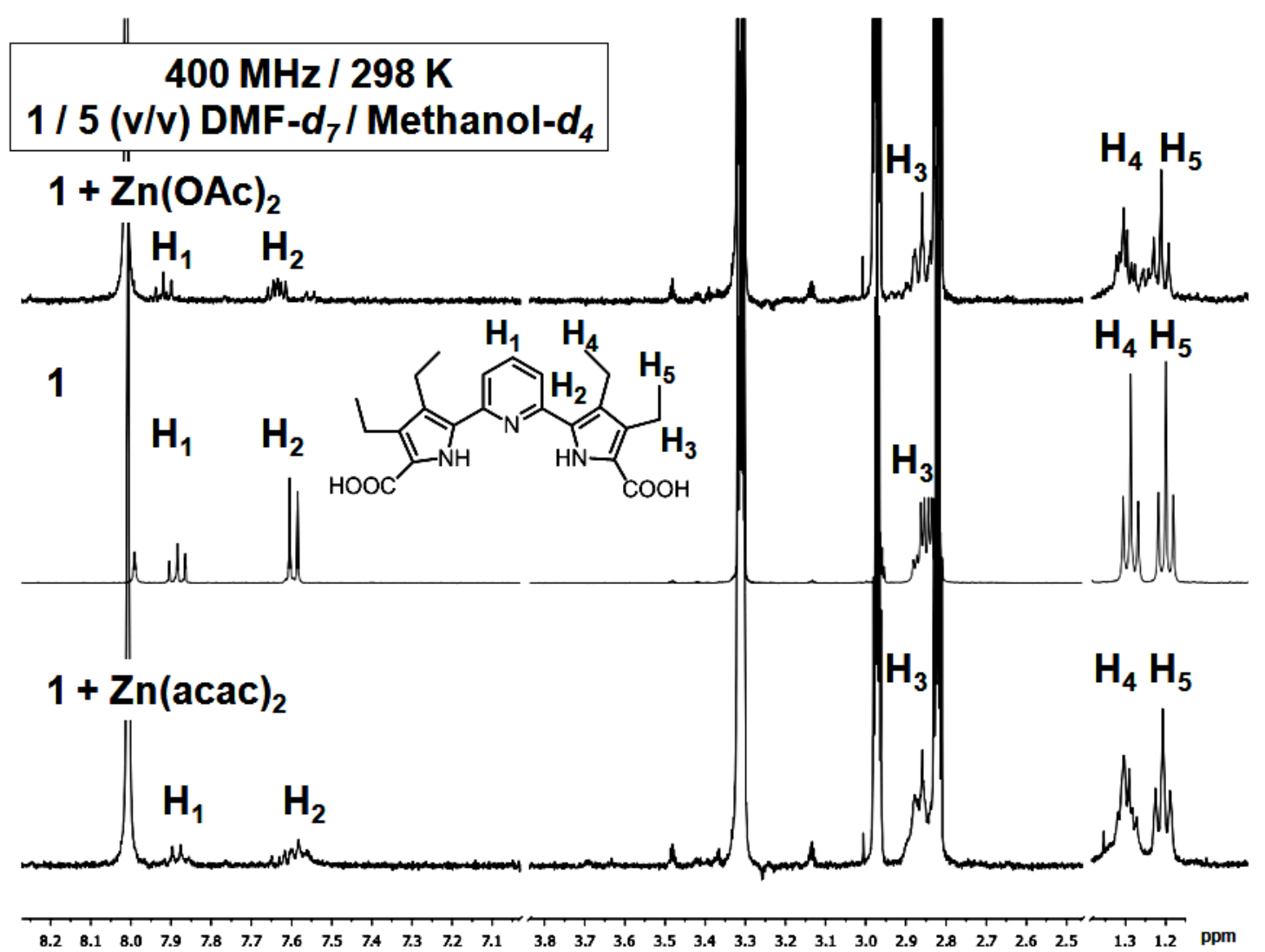

Figure S9. ${ }^{1} \mathrm{H}$ NMR spectra $\left(400 \mathrm{MHz}\right.$, room temperature) of compound $1\left(10^{-2} \mathrm{M}\right)$ recorded in the absence of $\mathrm{Zn}^{2+}$ (middle trace), in the presence of 1 equivalent of $\mathrm{Zn}(\mathrm{OAc})_{2}$ (top trace), and in the presence of 1 equivalent of $\mathrm{Zn}(\mathrm{acac})_{2}$ (bottom trace) in a mixed solvent system consisting of DMF- $d_{7}$ and methanol- $d_{4}(1: 5, \mathrm{v} / \mathrm{v})$. 
(a)

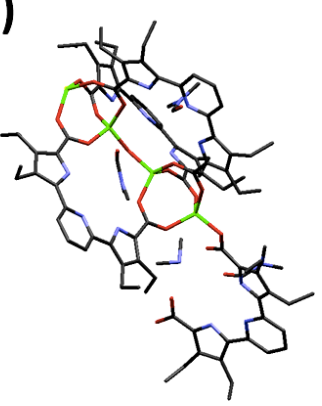

(b)

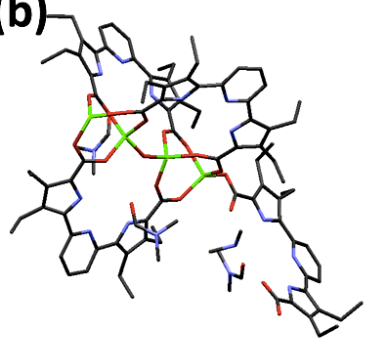

(c)

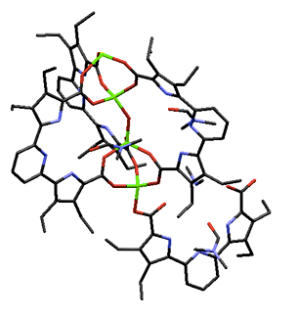

(d)

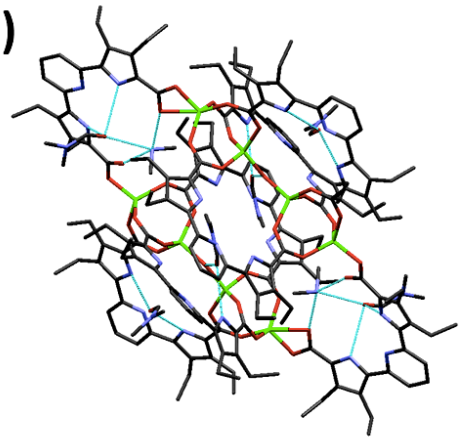

(e)

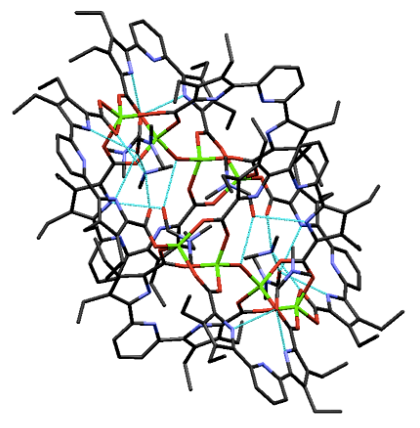

(f)

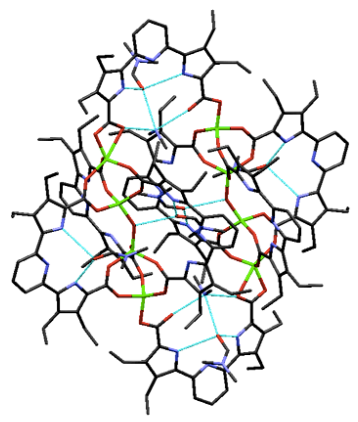

(h)

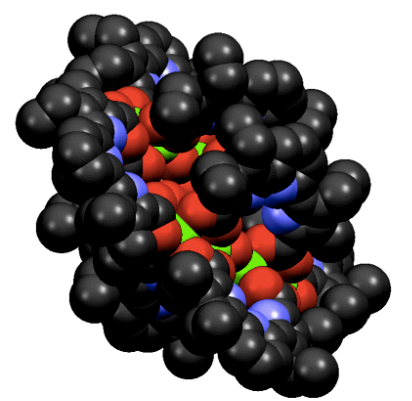

(i)

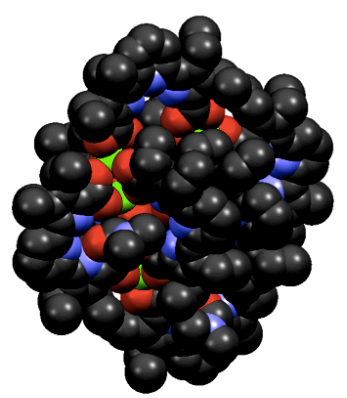

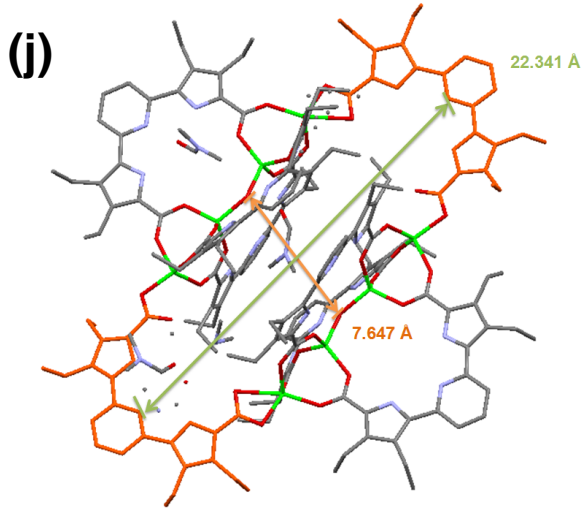

Figure S10. Coordination geometries of $\mathrm{Zn}$ sites and ligand bridging environment inferred from the crystal structures of cage-1 viewed along the a axis (a, d and g), b axis (b, e and h), and c axis (c, f, i) of the (a-c) asymmetric units, as well as the cages (d-f) shown in stick and (g-i) space-filling representations. The blue lines in d-f indicate the orientation of the presumed hydrogen bonds. (j) Selected metric parameters for the crystal structure of cage-1. The portions labeled in orange indicate the bridge-like ligands. Color: $\mathrm{C}$ gray, $\mathrm{N}$ blue, $\mathrm{O}$ red, $\mathrm{Zn}$ green. Hydrogen atoms have been omitted 
for clarity.

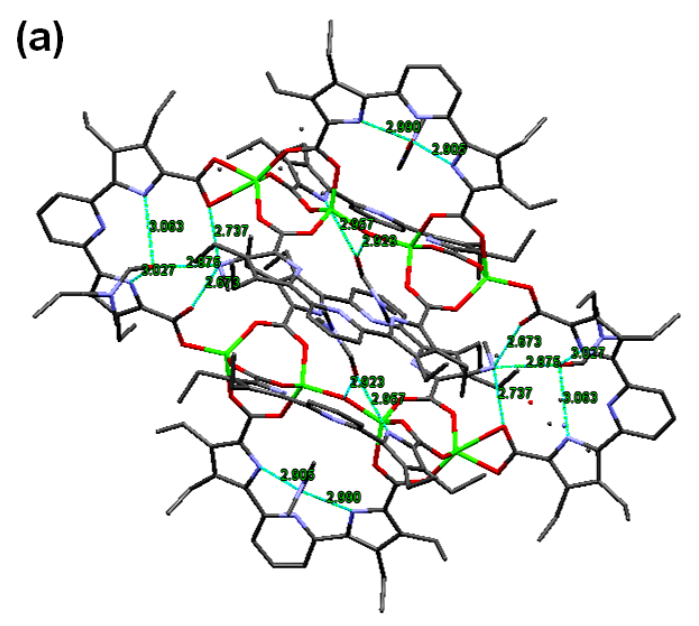

(b)
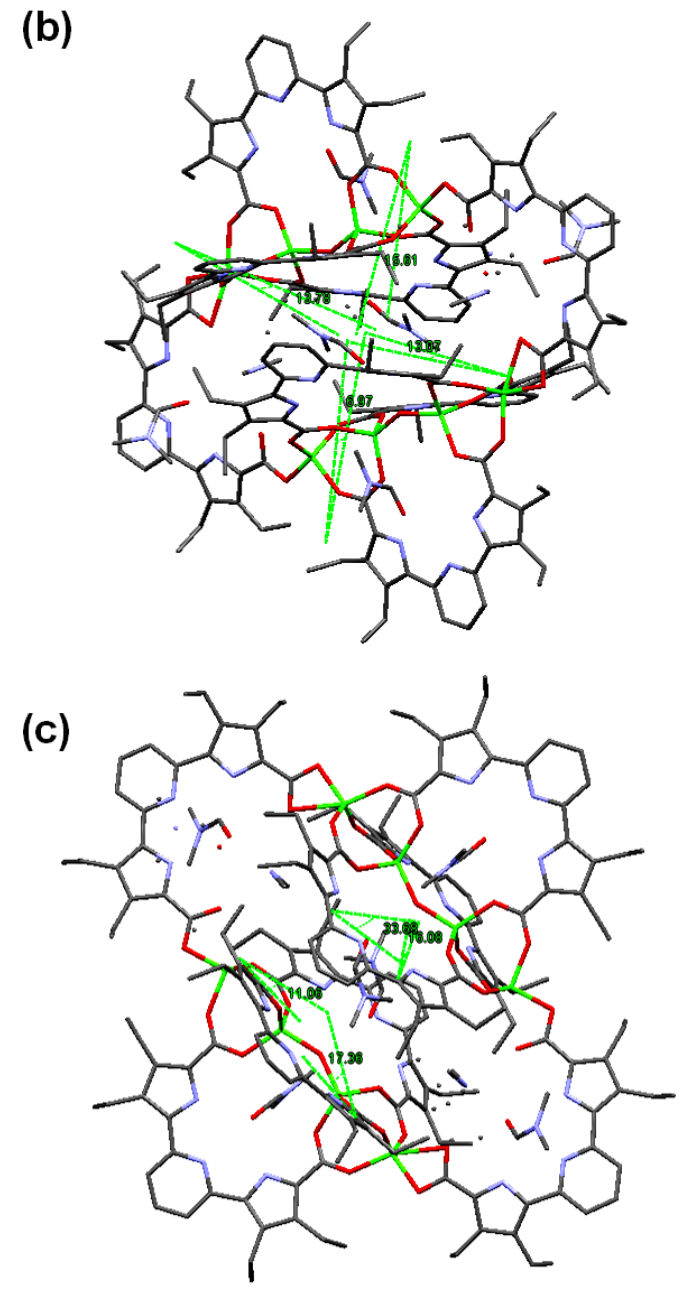

Figure S11. Hydrogen bonds (blue lines, a) and NCCN dihedral angles (b, c) inferred from the metric parameters of the crystal structure of cage-1. Values in part (a) indicate distances between two nearby 
nitrogen and oxygen atoms. Color: $\mathrm{C}$ gray, $\mathrm{N}$ blue, $\mathrm{O}$ red, $\mathrm{Zn}$ green. The hydrogen atoms have been omitted for clarity.
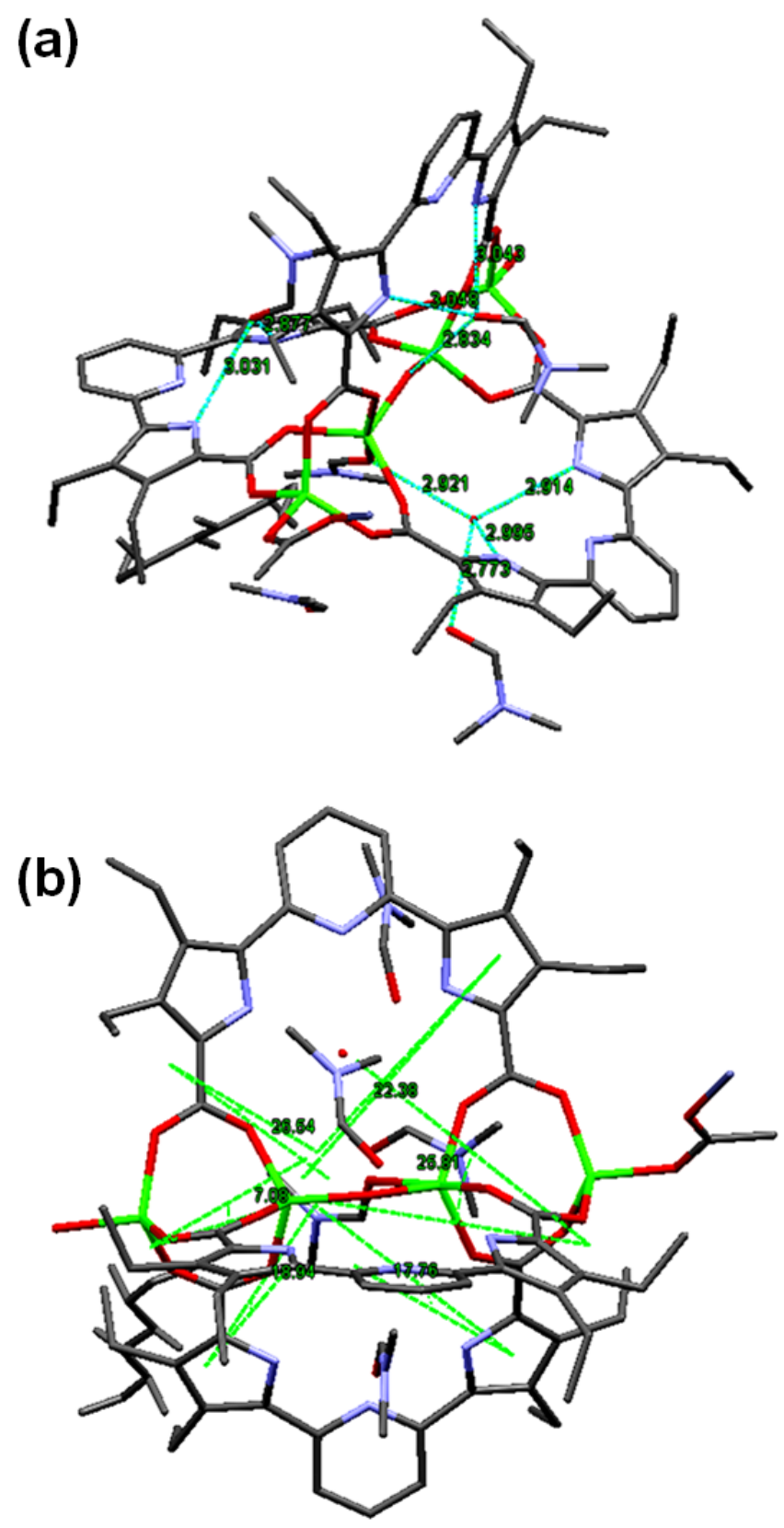

Figure S12. Selected hydrogen bonds (blue lines, a) and NCCN dihedral angles (b) inferred from the metric parameters of the crystal structure of cage-2. Values in part (a) indicate distances between two nearby nitrogen and oxygen atoms. Color: $\mathrm{C}$ gray, $\mathrm{N}$ blue, $\mathrm{O}$ red, $\mathrm{Zn}$ green. The hydrogen atoms have been omitted for clarity. 
(a)

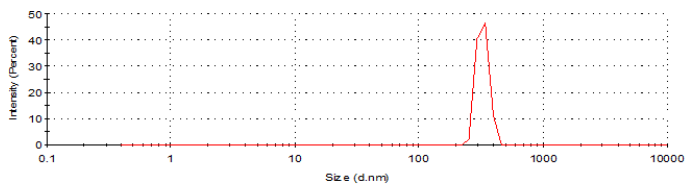

(b)

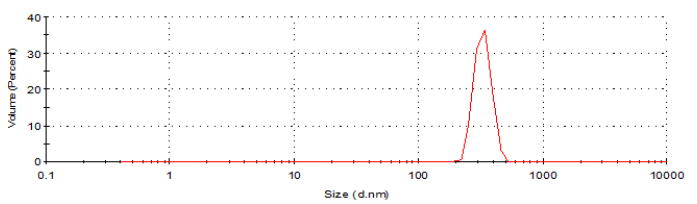

(c)

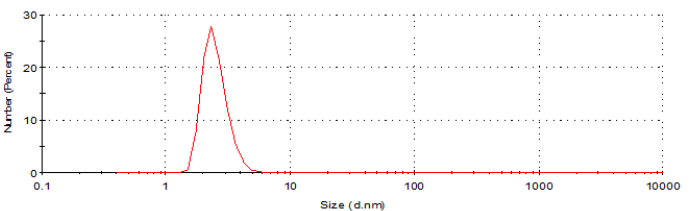

(d)

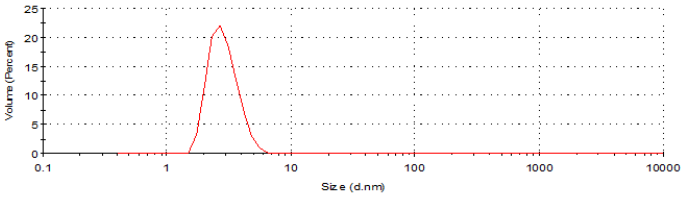

(e)

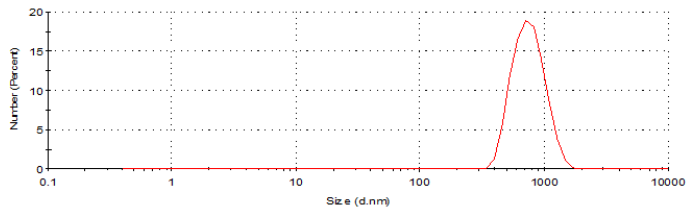

(f)

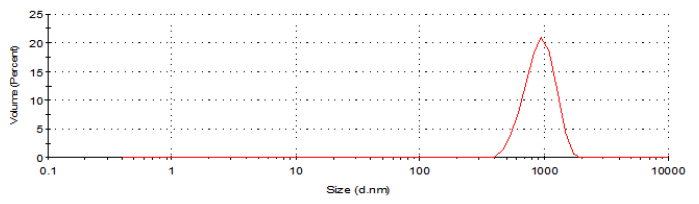

Figure S13. DLS size distribution of compound $1(1 \mathrm{mM})$ in the absence (a, after $4 \mathrm{~h} ; \mathrm{b}$, after $24 \mathrm{~h}$ ) and presence of $\mathrm{Zn}(\mathrm{acac})_{2}$ (c, after $4 \mathrm{~h}$; d, after $24 \mathrm{~h}$ ) or $\mathrm{Zn}(\mathrm{OAc})_{2}$ (e, after 4 hour; f, after 24 hour) at room temperature. 


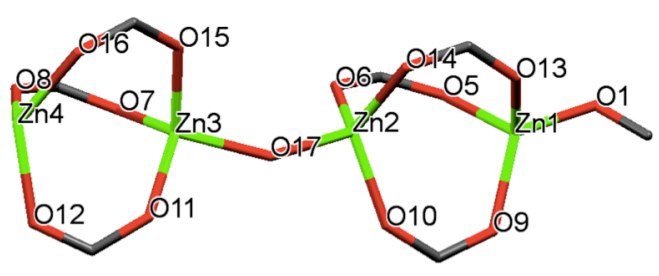

From cage-1

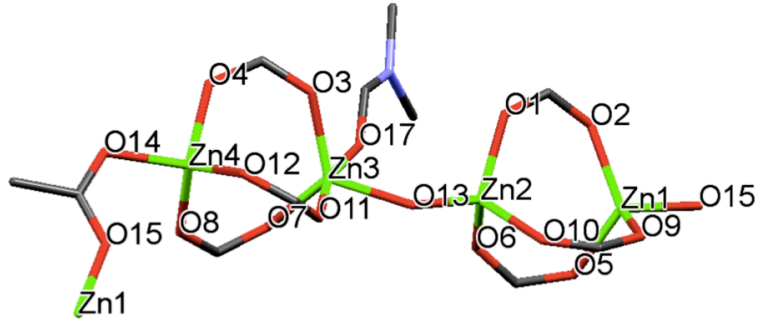

From cage-2

Table S1 Bond lengths $(\AA \AA)$ and angles $\left({ }^{\circ}\right)$ of zinc dimers from cage-1 and cage-2.

Cage-1

$\begin{array}{lllllll}\mathrm{Zn}(1)-\mathrm{O}(1) & 1.961 & \mathrm{Zn}(2)-\mathrm{O}(6) & 1.937 \mathrm{Zn}(3)-\mathrm{O}(7) & 1.943 & \mathrm{Zn}(4)-\mathrm{O}(8) & 1.985 \\ \mathrm{Zn}(1)-\mathrm{O}(5) & 1.990 & \mathrm{Zn}(2)-\mathrm{O}(10) & 1.942 \mathrm{Zn}(3)-\mathrm{O}(11) & 1.945 & \mathrm{Zn}(4)-\mathrm{O}(12) & 1.975 \\ \mathrm{Zn}(1)-\mathrm{O}(9) & 1.962 & \mathrm{Zn}(2)-\mathrm{O}(14) & 1.941 \mathrm{Zn}(3)-\mathrm{O}(15) & 1.933 & \mathrm{Zn}(4)-\mathrm{O}(16) & 1.977 \\ \mathrm{Zn}(1)-\mathrm{O}(13) & 1.982 & \mathrm{Zn}(2)-\mathrm{O}(17) & 1.918 \mathrm{Zn}(3)-\mathrm{O}(17) & 1.922 & \end{array}$

\begin{tabular}{|c|c|c|c|c|c|c|}
\hline $\mathrm{O}(1)-\mathrm{Zn}(1)-\mathrm{O}(5)$ & 96.95 & $\mathrm{O}(6)-\mathrm{Zn}(2)-\mathrm{O}(10)$ & 110.08 & $\mathrm{O}(7)-\mathrm{Zn}(3)-\mathrm{O}(11)$ & 113.87 & $\mathrm{O}(8)-\mathrm{Zn}(4)-\mathrm{O}(12) \quad 101.45$ \\
\hline $\mathrm{O}(1)-\mathrm{Zn}(1)-\mathrm{O}(9)$ & 118.23 & $\mathrm{O}(6)-\mathrm{Zn}(2)-\mathrm{O}(14)$ & 107.59 & $\mathrm{O}(7)-\mathrm{Zn}(3)-\mathrm{O}(15)$ & 104.86 & $\mathrm{O}(8)-\mathrm{Zn}(4)-\mathrm{O}(16) \quad 100.92$ \\
\hline $\mathrm{O}(1)-\mathrm{Zn}(1)-\mathrm{O}(13)$ & 109.28 & $\mathrm{O}(6)-\mathrm{Zn}(2)-\mathrm{O}(17)$ & 113.99 & $\mathrm{O}(7)-\mathrm{Zn}(3)-\mathrm{O}(17)$ & 117.39 & $\mathrm{O}(12)-\mathrm{Zn}(4)-\mathrm{O}(16) 129.65$ \\
\hline $\mathrm{O}(5)-\mathrm{Zn}(1)-\mathrm{O}(9)$ & 104.18 & $\mathrm{O}(10)-\mathrm{Zn}(2)-\mathrm{O}(14)$ & 120.01 & $\mathrm{O}(11)-\mathrm{Zn}(3)-\mathrm{O}(15)$ & 118.48 & \\
\hline $\mathrm{O}(5)-\mathrm{Zn}(1)-\mathrm{O}(13)$ & 109.18 & $\mathrm{O}(10)-\mathrm{Zn}(2)-\mathrm{O}(17)$ & 96.67 & $\mathrm{O}(11)-\mathrm{Zn}(3)-\mathrm{O}(17)$ & 96.98 & \\
\hline $\mathrm{O}(9)-\mathrm{Zn}(1)-\mathrm{O}(13)$ & 116.64 & $\mathrm{O}(14)-\mathrm{Zn}(2)-\mathrm{O}(17)$ & 108.42 & $\mathrm{O}(15)-\mathrm{Zn}(3)-\mathrm{O}(17)$ & 105.51 & \\
\hline
\end{tabular}

Cage-2

$\begin{array}{llllllll}\mathrm{Zn}(1)-\mathrm{O}(2) & 1.940 \mathrm{Zn}(2)-\mathrm{O}(1) & 1.940 & \mathrm{Zn}(3)-\mathrm{O}(3) & 1.956 & \mathrm{Zn}(4)-\mathrm{O}(4) & 1.963 \\ \mathrm{Zn}(1)-\mathrm{O}(5) & 1.953 \mathrm{Zn}(2)-\mathrm{O}(6) & 1.948 & \mathrm{Zn}(3)-\mathrm{O}(7) & 1.949 & \mathrm{Zn}(4)-\mathrm{O}(8) & 1.935 \\ \mathrm{Zn}(1)-\mathrm{O}(9) & 1.965 \mathrm{Zn}(2)-\mathrm{O}(10) & 1.988 & \mathrm{Zn}(3)-\mathrm{O}(11) & 2.107 & \mathrm{Zn}(4)-\mathrm{O}(12) & 1.946 \\ \mathrm{Zn}(1)-\mathrm{O}(15) & 1.952 \mathrm{Zn}(2)-\mathrm{O}(13) & 1.894 & \mathrm{Zn}(3)-\mathrm{O}(13) & 1.920 & \mathrm{Zn}(4)-\mathrm{O}(14) & 1.961 & \\ & & & \mathrm{Zn}(3)-\mathrm{O}(17) & 2.293 & & \\ \mathrm{O}(2)-\mathrm{Zn}(1)-\mathrm{O}(5) & 118.14 & \mathrm{O}(1)-\mathrm{Zn}(2)-\mathrm{O}(6) & 114.33 & \mathrm{O}(3)-\mathrm{Zn}(3)-\mathrm{O}(7) & 120.92 & \mathrm{O}(4)-\mathrm{Zn}(4)-\mathrm{O}(8) & 116.37 \\ \mathrm{O}(2)-\mathrm{Zn}(1)-\mathrm{O}(9) & 116.80 & \mathrm{O}(1)-\mathrm{Zn}(2)-\mathrm{O}(10) & 108.52 & \mathrm{O}(3)-\mathrm{Zn}(3)-\mathrm{O}(11) & 99.08 & \mathrm{O}(4)-\mathrm{Zn}(4)-\mathrm{O}(12) & 108.63 \\ \mathrm{O}(2)-\mathrm{Zn}(1)-\mathrm{O}(15) & 102.83 & \mathrm{O}(1)-\mathrm{Zn}(2)-\mathrm{O}(13) & 110.91 & \mathrm{O}(3)-\mathrm{Zn}(3)-\mathrm{O}(13) & 117.61 & \mathrm{O}(4)-\mathrm{Zn}(4)-\mathrm{O}(14) & 101.61\end{array}$




\section{X-Ray Experimental}

$\mathrm{X}$-ray experimental for the supramolecular polymeric form of 1: Crystals grew as colorless prisms via the vapor diffusion of hexanes into a dimethyl formamide solution of compound $\mathbf{1}$. The data crystal had approximate dimensions; $0.12 \times 0.06 \times 0.03 \mathrm{~mm}$. The data were collected on a Rigaku AFC12 diffractometer with a Saturn $724+$ CCD using a graphite monochromator with MoK $\alpha$ radiation $(\lambda=0.71073 \AA$ ). A total of 1644 frames of data were collected using $\omega$-scans with a scan range of $0.5^{\circ}$ and a counting time of 45 seconds per frame. The data were collected at $100 \mathrm{~K}$ using an Oxford Cryostream low temperature device. Details of crystal data, data collection and structure refinement are listed in Table S1. Data reduction were performed using the Rigaku Americas Corporation's Crystal Clear version 1.40. ${ }^{\mathrm{S} 3}$ The structure was solved by direct methods using SIR $2004^{\mathrm{S} 4}$ and refined by full-matrix least-squares on $\mathrm{F}^{2}$ with anisotropic displacement parameters for the non-H atoms using SHELXL-2014/7. ${ }^{\mathrm{S} 5}$ Structure analysis was aided by use of the programs PLATON98 ${ }^{\mathrm{S} 6}$ and WinGX. ${ }^{\mathrm{S} 7}$ The hydrogen atoms on carbon were calculated in ideal positions with isotropic displacement parameters set to $1.2 \mathrm{xUeq}$ of the attached atom (1.5xUeq for methyl hydrogen atoms). The hydrogen atoms bound to nitrogen and oxygen were located in a $\Delta \mathrm{F}$ map and refined with isotropic displacement parameters.

The function, $\Sigma \mathrm{w}\left(\left|\mathrm{F}_{\mathrm{O}}\right|^{2}-\left|\mathrm{F}_{\mathrm{c}}\right|^{2}\right)^{2}$, was minimized, where $\mathrm{w}=1 /\left[\left(\sigma\left(\mathrm{F}_{\mathrm{O}}\right)\right)^{2}+(0.0513 * \mathrm{P})^{2}+\right.$ $\left.\left(0.4916^{*} \mathrm{P}\right)\right]$ and $\mathrm{P}=\left(\left|\mathrm{F}_{\mathrm{O}}\right|^{2}+2\left|\mathrm{~F}_{\mathrm{c}}\right|^{2}\right) / 3 . \mathrm{R}_{\mathrm{W}}\left(\mathrm{F}^{2}\right)$ refined to 0.153 , with $\mathrm{R}(\mathrm{F})$ equal to 0.0639 and a goodness of fit, $\mathrm{S},=1.08$. Definitions used for calculating $\mathrm{R}(\mathrm{F}), \mathrm{R}_{\mathrm{W}}\left(\mathrm{F}^{2}\right)$ and the goodness of fit, $\mathrm{S}$, are given below. The data were checked for secondary extinction effects but no correction was necessary. Neutral atom scattering factors and values used to calculate the linear absorption coefficient are from the International Tables for X-ray Crystallography (1992). ${ }^{\text {S9 }}$ All figures were generated using SHELXTL/PC. ${ }^{\mathrm{S} 10}$ Tables of positional and thermal parameters, bond lengths and angles, torsion angles and figures are in the CIF. CCDC deposition number: 1447409.

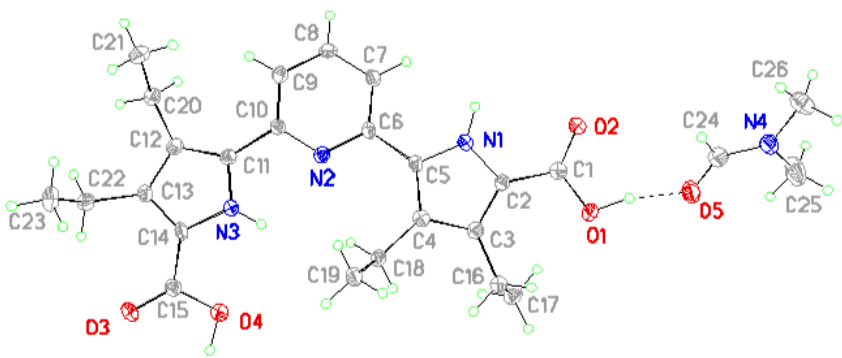

Figure S14. View of 1 showing the atom labeling scheme. Displacement ellipsoids are scaled to the $50 \%$ probability level. 
Table S2 Crystal data and structure refinement for the supramolecular polymer of $\mathbf{1}$.

\begin{tabular}{|c|c|c|}
\hline Empirical formula & \multicolumn{2}{|l|}{$\mathrm{C}_{26} \mathrm{H}_{34} \mathrm{~N}_{4} \mathrm{O}_{5}$} \\
\hline Formula weight & \multicolumn{2}{|l|}{482.57} \\
\hline Temperature & \multicolumn{2}{|l|}{$100(2) \mathrm{K}$} \\
\hline Wavelength & \multicolumn{2}{|l|}{$0.71073 \AA$} \\
\hline Crystal system & \multicolumn{2}{|l|}{ triclinic } \\
\hline Space group & \multicolumn{2}{|l|}{$P-1$} \\
\hline \multirow[t]{3}{*}{ Unit cell dimensions } & $\mathrm{a}=4.9105(19) \AA$ & $\alpha=85.058(10)^{\circ}$. \\
\hline & $\mathrm{b}=10.503(4) \AA$ & $\beta=88.604(8)^{\circ}$. \\
\hline & $\mathrm{c}=24.057(10) \AA$ & $\gamma=88.473(11)^{\circ}$. \\
\hline Volume & \multicolumn{2}{|l|}{$1235.4(8) \AA^{3}$} \\
\hline Z & \multicolumn{2}{|l|}{2} \\
\hline Density (calculated) & \multicolumn{2}{|l|}{$1.297 \mathrm{Mg} / \mathrm{m}^{3}$} \\
\hline Absorption coefficient & \multicolumn{2}{|l|}{$0.091 \mathrm{~mm}^{-1}$} \\
\hline $\mathrm{F}(000)$ & \multicolumn{2}{|l|}{516} \\
\hline Crystal size & \multicolumn{2}{|c|}{$0.120 \times 0.060 \times 0.030 \mathrm{~mm}^{3}$} \\
\hline Theta range for data collection & \multicolumn{2}{|l|}{3.074 to $27.475^{\circ}$. } \\
\hline Index ranges & \multicolumn{2}{|c|}{$-6<=\mathrm{h}<=6,-13<=\mathrm{k}<=13,-31<=1<=31$} \\
\hline Reflections collected & \multicolumn{2}{|l|}{22925} \\
\hline Independent reflections & \multicolumn{2}{|c|}{$5600[\mathrm{R}(\mathrm{int})=0.0943]$} \\
\hline Completeness to theta $=25.242^{\circ}$ & \multicolumn{2}{|l|}{$99.6 \%$} \\
\hline Absorption correction & \multicolumn{2}{|c|}{ Semi-empirical from equivalents } \\
\hline Max. and min. transmission & \multicolumn{2}{|l|}{1.00 and 0.624} \\
\hline Refinement method & \multicolumn{2}{|c|}{ Full-matrix least-squares on $\mathrm{F}^{2}$} \\
\hline Data / restraints / parameters & \multicolumn{2}{|l|}{$5600 / 0 / 338$} \\
\hline Goodness-of-fit on $\mathrm{F}^{2}$ & \multicolumn{2}{|l|}{1.079} \\
\hline Final $R$ indices $[\mathrm{I}>2 \operatorname{sigma}(\mathrm{I})]$ & \multicolumn{2}{|c|}{$\mathrm{R} 1=0.0639, \mathrm{wR} 2=0.1339$} \\
\hline $\mathrm{R}$ indices (all data) & \multicolumn{2}{|c|}{$\mathrm{R} 1=0.1119, \mathrm{wR} 2=0.1529$} \\
\hline Extinction coefficient & \multicolumn{2}{|l|}{$\mathrm{n} / \mathrm{a}$} \\
\hline Largest diff. peak and hole & \multicolumn{2}{|c|}{0.248 and -0.354 e. $\AA^{-3}$} \\
\hline
\end{tabular}


X-ray experimental for the dimer of 1 produced upon treatment with TBAOAc: Crystals grew as colorless plates via the vapor diffusion of hexanes into a solution of the sample in dimethyl formamide and methanol. The data were collected on a Rigaku ACF-12 with a Saturn 724+ CCD using a graphite monochromator with MoK $\alpha$ radiation $(\lambda=0.71073 \AA)$. A total of 11104 frames of data were collected using $\omega$-scans with a scan range of $0.5^{\circ}$ and a counting time of 45 seconds per frame. The data were collected at $100 \mathrm{~K}$ using a Rigaku XStream low temperature device. Details of crystal data, data collection and structure refinement are listed in Table 1. Data reduction were performed using the Rigaku Americas Corporation's Crystal Clear version $1.40 .{ }^{\mathrm{S} 3}$ The structure was solved by direct methods using Superflip ${ }^{\mathrm{S} 4}$ and refined by full-matrix least-squares on $\mathrm{F}^{2}$ with anisotropic displacement parameters for the non-H atoms using SHELXL-97. ${ }^{\text {S5 }}$

Two of the n-butyl arms on the cation were disordered. The disorder involved the ethyl portion in each instance. One arm was disordered about two positions, while three different orientations of the ethyl group were used for the second disordered group. Both were modeled in a similar fashion. The geometry of the ethyl groups was restrained to be equivalent throughout the refinement. For the ethyl group with three orientations, a SUMP command was used so that the sum of the site occupancy factors for the three arrangements was set to unity. Hydrogen atoms were calculated in ideal positions.

The large region around $0,0.16,0.67$ was occupied by a disordered molecule of dichloromethane. Attempts to model the disorder were unsatisfactory. The contributions to the scattering factors due to this solvent molecule were removed by use of the utility SQUEEZE ${ }^{\mathrm{S} 6}$ in PLATON98. ${ }^{\mathrm{S} 7}$ Structure analysis was aided by use of the programs PLATON98 as incorporated into WinGX. ${ }^{\mathrm{S} 8}$ The hydrogen atoms on carbon were calculated in ideal positions with isotropic displacement parameters set to $1.2 x U e q$ of the attached atom ( $1.5 \mathrm{xUeq}$ for methyl hydrogen atoms). The hydrogen atoms on the pyrrole nitrogen atoms, the water molecule and the carboxylic acid were observed in a $\Delta \mathrm{F}$ map and refined with isotropic displacement parameters.

The function, $\Sigma \mathrm{w}\left(\left|\mathrm{F}_{\mathrm{O}}\right|^{2}-\left|\mathrm{F}_{\mathrm{c}}\right|^{2}\right)^{2}$, was minimized, where $\mathrm{w}=1 /\left[\left(\sigma\left(\mathrm{F}_{\mathrm{O}}\right)\right)^{2}+(0.0632 * \mathrm{P})^{2}+\right.$ (3.3513*P)] and $\mathrm{P}=\left(\left|\mathrm{F}_{\mathrm{O}}\right|^{2}+2\left|\mathrm{~F}_{\mathrm{C}}\right|^{2}\right) / 3 . \quad \mathrm{R}_{\mathrm{W}}\left(\mathrm{F}^{2}\right)$ refined to 0.133 , with $\mathrm{R}(\mathrm{F})$ equal to 0.0513 and a goodness of fit, $\mathrm{S},=1.04$. Definitions used for calculating $\mathrm{R}(\mathrm{F}), \mathrm{R}_{\mathrm{W}}\left(\mathrm{F}^{2}\right)$ and the goodness of fit, $\mathrm{S}$, are given below. ${ }^{\text {S8 }}$ The data were checked for secondary extinction effects but no correction was necessary. Neutral atom scattering factors and values used to calculate the linear absorption coefficient are from the International Tables for X-ray Crystallography (1992). . All figures were generated using SHELXTL/PC. ${ }^{\text {S10 }}$ Tables of positional and thermal parameters, bond lengths and angles, torsion angles and figures are found in the CIF. CCDC deposition number: 1447410. 


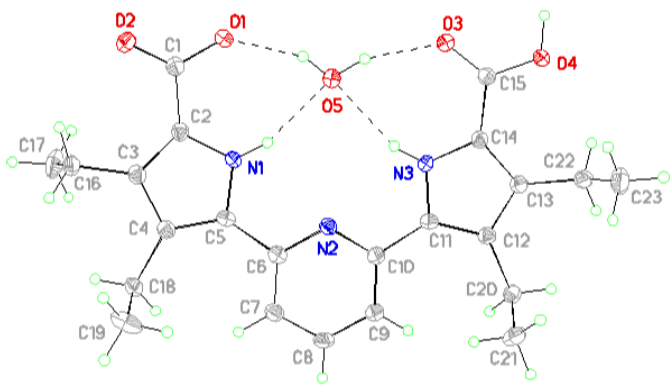

Figure S15. View of anion-water complex of 1 showing the atom labeling scheme. Displacement ellipsoids are scaled to the $50 \%$ probability level.

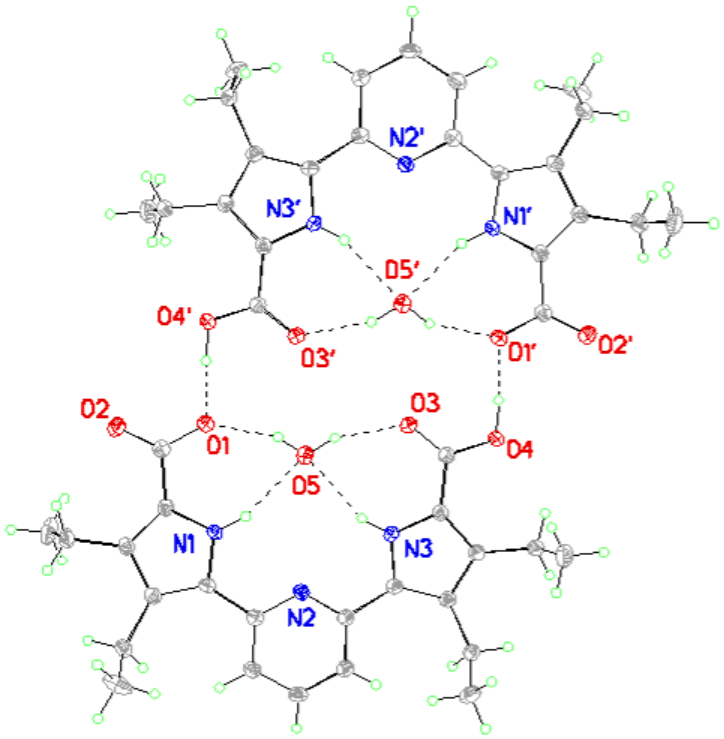

Figure S16. View of anion-water H-bound dimer of 1 produced upon treatment with TBAOAc showing the heteroatom labeling scheme. Displacement ellipsoids are scaled to the $50 \%$ probability level. The dimer sits around a crystallographic inversion center at $1 / 2,1,1 / 2$. 
Table S3 Crystal data and structure refinement for the dimer of $\mathbf{1 .}$

\begin{tabular}{|c|c|c|}
\hline Empirical formula & \multicolumn{2}{|c|}{$\mathrm{C} 39.50 \mathrm{H} 65 \mathrm{C} 1 \mathrm{~N} 4 \mathrm{O} 5$} \\
\hline Formula weight & \multicolumn{2}{|l|}{711.40} \\
\hline Temperature & \multicolumn{2}{|l|}{$100(2) \mathrm{K}$} \\
\hline Wavelength & \multicolumn{2}{|l|}{$0.71073 \AA$} \\
\hline Crystal system & \multicolumn{2}{|l|}{ monoclinic } \\
\hline Space group & \multicolumn{2}{|l|}{$\mathrm{P} 21 / \mathrm{c}$} \\
\hline \multirow[t]{3}{*}{ Unit cell dimensions } & $\mathrm{a}=18.156(3) \AA$ & $\alpha=90^{\circ}$. \\
\hline & $\mathrm{b}=9.0535(12) \AA$ & $\beta=106.877(4)^{\circ}$. \\
\hline & $\mathrm{c}=25.803(4)$ & $\gamma=90^{\circ}$. \\
\hline Volume & \multicolumn{2}{|l|}{$4058.8(10) \AA^{3}$} \\
\hline Z & \multicolumn{2}{|l|}{4} \\
\hline Density (calculated) & \multicolumn{2}{|l|}{$1.164 \mathrm{Mg} / \mathrm{m}^{3}$} \\
\hline Absorption coefficient & \multicolumn{2}{|l|}{$0.139 \mathrm{~mm}^{-1}$} \\
\hline $\mathrm{F}(000)$ & \multicolumn{2}{|l|}{1548} \\
\hline Theta range for data collection & \multicolumn{2}{|l|}{3.165 to $25.025^{\circ}$. } \\
\hline Index ranges & \multicolumn{2}{|c|}{$-20<=\mathrm{h}<=21,-10<=\mathrm{k}<=10,-30<=1<=30$} \\
\hline Reflections collected & \multicolumn{2}{|l|}{49564} \\
\hline Independent reflections & \multicolumn{2}{|c|}{$7162[\mathrm{R}(\mathrm{int})=0.0387]$} \\
\hline Completeness to theta $=25.025^{\circ}$ & \multicolumn{2}{|l|}{$99.8 \%$} \\
\hline Refinement method & \multicolumn{2}{|c|}{ Full-matrix least-squares on $\mathrm{F}^{2}$} \\
\hline Data / restraints / parameters & \multicolumn{2}{|l|}{$7162 / 79 / 492$} \\
\hline Goodness-of-fit on $\mathrm{F}^{2}$ & \multicolumn{2}{|l|}{1.009} \\
\hline Final $R$ indices $[\mathrm{I}>2 \operatorname{sigma}(\mathrm{I})]$ & \multicolumn{2}{|c|}{$\mathrm{R} 1=0.0513, \mathrm{wR} 2=0.1266$} \\
\hline $\mathrm{R}$ indices (all data) & \multicolumn{2}{|c|}{$\mathrm{R} 1=0.0602, \mathrm{wR} 2=0.1327$} \\
\hline Extinction coefficient & \multicolumn{2}{|l|}{$\mathrm{n} / \mathrm{a}$} \\
\hline Largest diff. peak and hole & \multicolumn{2}{|c|}{0.713 and -0.358 e. $\AA^{-3}$} \\
\hline
\end{tabular}


X-ray experimental for cage-1: Crystals grew as colorless plates via the vapor diffusion of hexanes into a solution of $\mathbf{1}$ in a mixed solvent consisting of methanol and dimethyl formamide. The data crystal had approximate dimensions; $0.16 \times 0.08 \times 0.05 \mathrm{~mm}$. The data were collected on an Agilent Technologies SuperNova Dual Source diffractometer using a $\mu$-focus $\mathrm{Cu} K \alpha$ radiation source $(\lambda=$ $1.5418 \AA$ ) with collimating mirror monochromators. A total of 1287 frames of data were collected using $\omega$-scans with a scan range of $1^{\circ}$ and a counting time of 9 seconds per frame with a detector offset of $+/-41.0^{\circ}$ and 30 seconds per frame with a detector offset of $+/-108.3^{\circ}$. The data were collected at $100 \mathrm{~K}$ using an Oxford Cryostream low temperature device. Details of crystal data, data collection and structure refinement are listed in Table S3. Data collection, unit cell refinement and data reduction were performed using Agilent Technologies CrysAlisPro V 1.171.37.31. ${ }^{\mathrm{S} 3}$ The structure was solved by direct methods using SuperFlip ${ }^{\mathrm{S} 4}$ and refined by full-matrix least-squares on $\mathrm{F}^{2}$ with anisotropic displacement parameters for the non-H atoms using SHELXL-2013. ${ }^{\mathrm{S} 5}$ Structure analysis was aided by use of the programs PLATON98 ${ }^{\mathrm{S} 6}$ and WinGX. ${ }^{\mathrm{S} 7}$ Most hydrogen atoms were calculated in ideal positions with isotropic displacement parameters set to $1.2 \mathrm{xUeq}$ of the attached atom (1.5xUeq for methyl hydrogen atoms). The hydrogen atoms bound to the hydroxide oxygen atom, $\mathrm{O} 17$, the nitrogen atom on the disordered pyrrole ring and the nitrogen atom of the dimethyl ammonium ion, $\mathrm{N} 17$, were observed in a $\Delta \mathrm{F}$ map and refined with isotropic displacement parameters.

One of the diethyl pyrrole groups was disordered. The disorder was due to a rocking about the $\mathrm{C}-\mathrm{C}$ bonds connecting the group to the remainder of the macrocycle. The disorder was modeled by assigning the variable $\mathrm{x}$ to the site occupancy factors for one component of the disorder. The site occupancy factors for the alternate component were set to (1-x). The geometry of the two components was restrained to be equivalent throughout the refinement. The variable $\mathrm{x}$ was refined while refining a common isotropic displacement parameter for all the atoms involved. In this way, the major component had a site occupancy of 73(2)\%. The disordered methyl group bound to C 85 was modeled in a similar fashion.

The function, $\Sigma \mathrm{w}\left(\left|\mathrm{F}_{\mathrm{O}}\right|^{2}-\left|\mathrm{F}_{\mathrm{c}}\right|^{2}\right)^{2}$, was minimized, where $\mathrm{w}=1 /\left[\left(\sigma\left(\mathrm{F}_{\mathrm{O}}\right)\right)^{2}+\left(0.0398^{*} \mathrm{P}\right)^{2}+\right.$ (4.7091*P)] and $\mathrm{P}=\left(\left|\mathrm{F}_{\mathrm{O}}\right|^{2}+2\left|\mathrm{~F}_{\mathrm{C}}\right|^{2}\right) / 3 . \quad \mathrm{R}_{\mathrm{W}}\left(\mathrm{F}^{2}\right)$ refined to 0.0880 , with $\mathrm{R}(\mathrm{F})$ equal to 0.0338 and a goodness of fit, $\mathrm{S},=1.14$. Definitions used for calculating $\mathrm{R}(\mathrm{F}), \mathrm{R}_{\mathrm{W}}\left(\mathrm{F}^{2}\right)$ and the goodness of fit, $\mathrm{S}$, are given below. ${ }^{\text {S8 }}$ The data were checked for secondary extinction effects but no correction was necessary. Neutral atom scattering factors and values used to calculate the linear absorption coefficient are from the International Tables for X-ray Crystallography (1992). . All figures were generated using SHELXTL/PC. ${ }^{\text {S10 }}$ Tables of positional and thermal parameters, bond lengths and angles, torsion angles and figures are found in the CIF. CCDC deposition number: 1447411. 

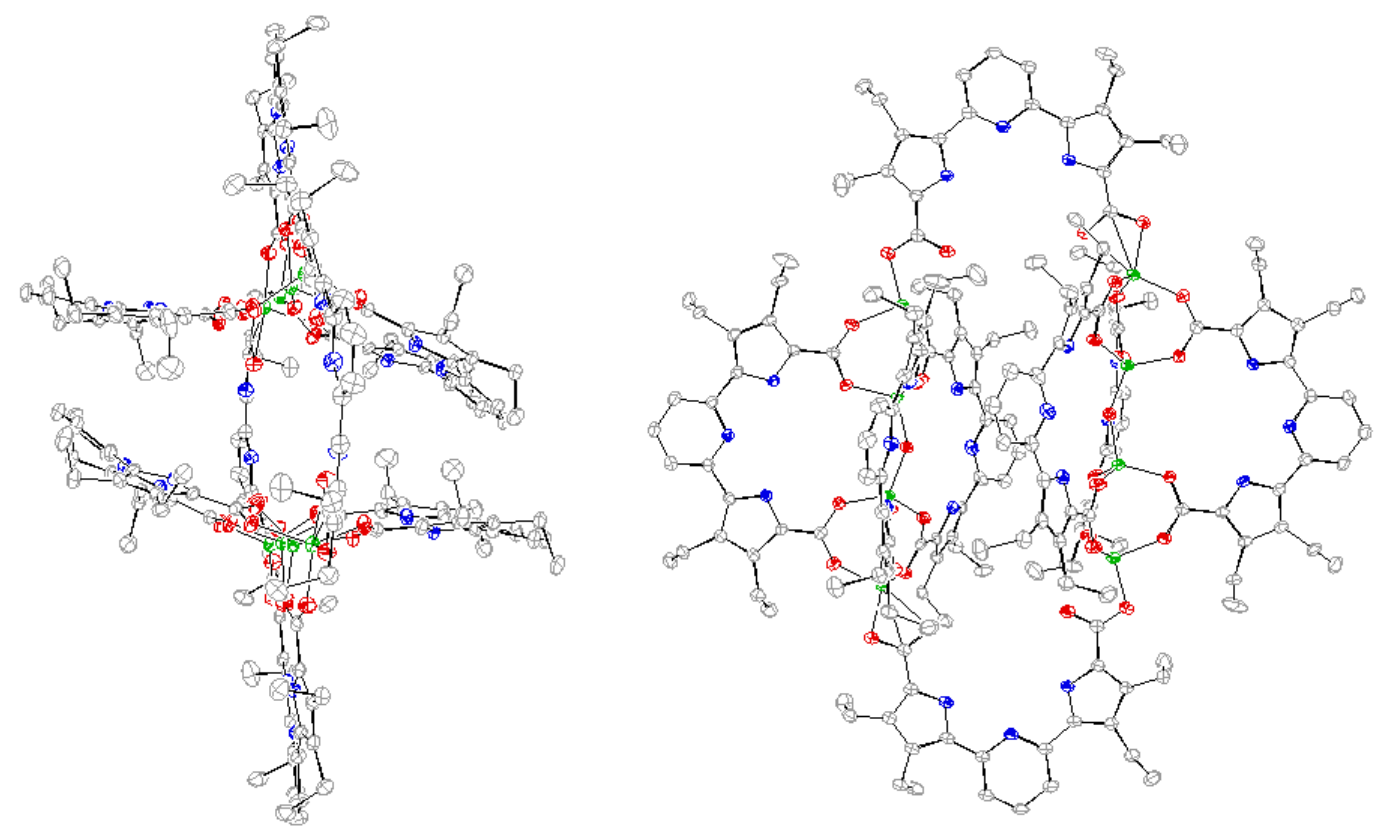

Figure S17. Two views of cage-1. Displacement ellipsoids are scaled to the $50 \%$ probability level. The hydrogen atoms were omitted for clarity. 
Table S4 Crystal data and structure refinement for cage-1.

\begin{tabular}{|c|c|c|}
\hline Empirical formula & \multicolumn{2}{|c|}{$\mathrm{C}_{209} \mathrm{H}_{267} \mathrm{~N}_{33} \mathrm{O}_{41} \mathrm{Zn}_{8}$} \\
\hline Formula weight & \multicolumn{2}{|l|}{4420.50} \\
\hline Temperature & \multicolumn{2}{|l|}{$100(2) \mathrm{K}$} \\
\hline Wavelength & \multicolumn{2}{|l|}{$1.54184 \AA$} \\
\hline Crystal system & \multicolumn{2}{|l|}{ triclinic } \\
\hline Space group & \multicolumn{2}{|l|}{$P-1$} \\
\hline \multirow[t]{3}{*}{ Unit cell dimensions } & $a=15.916(5) \AA$ & $\alpha=105.094(4)^{\circ}$. \\
\hline & $\mathrm{b}=18.830(6) \AA$ & $\beta=103.903(4)^{\circ}$. \\
\hline & $\mathrm{c}=19.364(6) \AA$ & $\gamma=91.781(5)^{\circ}$ \\
\hline Volume & \multicolumn{2}{|l|}{$5412(3) \AA^{3}$} \\
\hline $\mathrm{Z}$ & \multicolumn{2}{|l|}{1} \\
\hline Density (calculated) & \multicolumn{2}{|l|}{$1.356 \mathrm{Mg} / \mathrm{m}^{3}$} \\
\hline Absorption coefficient & \multicolumn{2}{|l|}{$1.616 \mathrm{~mm}^{-1}$} \\
\hline $\mathrm{F}(000)$ & \multicolumn{2}{|l|}{2320} \\
\hline Crystal size & \multicolumn{2}{|c|}{$0.16 \times 0.08 \times 0.05 \mathrm{~mm}$} \\
\hline Theta range for data collection & \multicolumn{2}{|l|}{2.875 to $74.089^{\circ}$. } \\
\hline Index ranges & \multicolumn{2}{|c|}{$-18<=\mathrm{h}<=19,-21<=\mathrm{k}<=23,-23<=1<=22$} \\
\hline Reflections collected & \multicolumn{2}{|l|}{41174} \\
\hline Independent reflections & \multicolumn{2}{|c|}{$21005[\mathrm{R}(\mathrm{int})=0.0199]$} \\
\hline Completeness to theta $=67.684^{\circ}$ & \multicolumn{2}{|l|}{$99.1 \%$} \\
\hline Absorption correction & \multicolumn{2}{|c|}{ Semi-empirical from equivalents } \\
\hline Max. and min. transmission & \multicolumn{2}{|l|}{1.00 and 0.921} \\
\hline Refinement method & \multicolumn{2}{|c|}{ Full-matrix least-squares on $\mathrm{F}^{2}$} \\
\hline Data / restraints / parameters & \multicolumn{2}{|c|}{$21005 / 365 / 1444$} \\
\hline Goodness-of-fit on $\mathrm{F}^{2}$ & \multicolumn{2}{|l|}{0.977} \\
\hline Final $R$ indices $[\mathrm{I}>2 \operatorname{sigma}(\mathrm{I})]$ & \multicolumn{2}{|c|}{$\mathrm{R} 1=0.0338, \mathrm{wR} 2=0.0831$} \\
\hline $\mathrm{R}$ indices (all data) & \multicolumn{2}{|c|}{$\mathrm{R} 1=0.0428, \mathrm{wR} 2=0.0880$} \\
\hline Extinction coefficient & \multicolumn{2}{|l|}{$\mathrm{n} / \mathrm{a}$} \\
\hline Largest diff. peak and hole & \multicolumn{2}{|c|}{0.601 and -0.502 e. $\AA^{-3}$} \\
\hline
\end{tabular}


X-ray experimental for polymeric cage-2: Crystals grew as colorless prisms by vapor diffusion of n-hexanes into a DMF solution of the complex. The datum crystal was cut from a larger crystal and had approximate dimensions; $0.32 \times 0.16 \times 0.08 \mathrm{~mm}$. The data were collected on a Rigaku ACF-12 with a Saturn $724+$ CCD using a graphite monochromator with MoK $\alpha$ radiation $(\lambda=0.71075 \AA)$. A total of 1404 frames of data were collected using $\omega$-scans with a scan range of $0.5^{\circ}$ and a counting time of 45 seconds per frame. The data were collected at $100 \mathrm{~K}$ using a Rigaku XStream low temperature device. Details of crystal data, data collection and structure refinement are listed in Table S4. Data reduction were performed using the Rigaku Americas Corporation's Crystal Clear version 1.40 . $^{\mathrm{S} 3}$ The structure was solved by direct methods using Superflip ${ }^{\mathrm{S} 4}$ and refined by full-matrix least-squares on $\mathrm{F}^{2}$ with anisotropic displacement parameters for the non- $\mathrm{H}$ atoms using SHELXL-2014/7. ${ }^{\text {S5 }}$ The hydrogen atoms on carbon were calculated in ideal positions with isotropic displacement parameters set to $1.2 \mathrm{xUeq}$ of the attached atom (1.5xUeq for methyl hydrogen atoms). The hydrogen atoms bond to the pyrrole nitrogen atoms and the oxygen atoms were observed in a $\Delta \mathrm{F}$ map and refined with isotropic displacement parameters.

A molecule of n-hexane was disordered near a crystallographic inversion center at $0,0,1 / 2$. The electron density in this region was too low to be due to a fully occupied n-hexane molecule. The electron count calculated by SQUEEZE amounted to 27 electrons, which amounts to what is expected for a quarter occupancy molecule. Attempts to model the disorder were unsatisfactory. The contributions to the scattering factors due to this solvent molecule were removed by use of the utility SQUEEZE $^{\text {S6 }}$ in PLATON98. ${ }^{\text {S7 }}$ Structure analysis was aided by use of the programs PLATON98 as incorporated into WinGX.

The function, $\Sigma \mathrm{w}\left(\left|\mathrm{F}_{\mathrm{O}}\right|^{2}-\left|\mathrm{F}_{\mathrm{c}}\right|^{2}\right)^{2}$, was minimized, where $\mathrm{w}=1 /\left[\left(\sigma\left(\mathrm{F}_{\mathrm{O}}\right)\right)^{2}+(0.0108 * \mathrm{P})^{2}+\right.$ $(21.7329 * \mathrm{P})]$ and $\mathrm{P}=\left(\left|\mathrm{F}_{\mathrm{O}}\right|^{2}+2\left|\mathrm{~F}_{\mathrm{C}}\right|^{2}\right) / 3 . \mathrm{R}_{\mathrm{W}}\left(\mathrm{F}^{2}\right)$ refined to 0.100 , with $\mathrm{R}(\mathrm{F})$ equal to 0.0544 and a goodness of fit, $\mathrm{S},=1.08$. Definitions used for calculating $\mathrm{R}(\mathrm{F}), \mathrm{R}_{\mathrm{W}}\left(\mathrm{F}^{2}\right)$ and the goodness of fit, $\mathrm{S}$, are given below. ${ }^{\text {S8 }}$ The data were checked for secondary extinction effects but no correction was necessary. Neutral atom scattering factors and values used to calculate the linear absorption coefficient are from the International Tables for X-ray Crystallography (1992). ${ }^{\text {S9 }}$ All figures were generated using SHELXTL/PC. ${ }^{\text {S10 }}$ Tables of positional and thermal parameters, bond lengths and angles, torsion angles and figures are found in the CIF. CCDC deposition number: 1447412. 


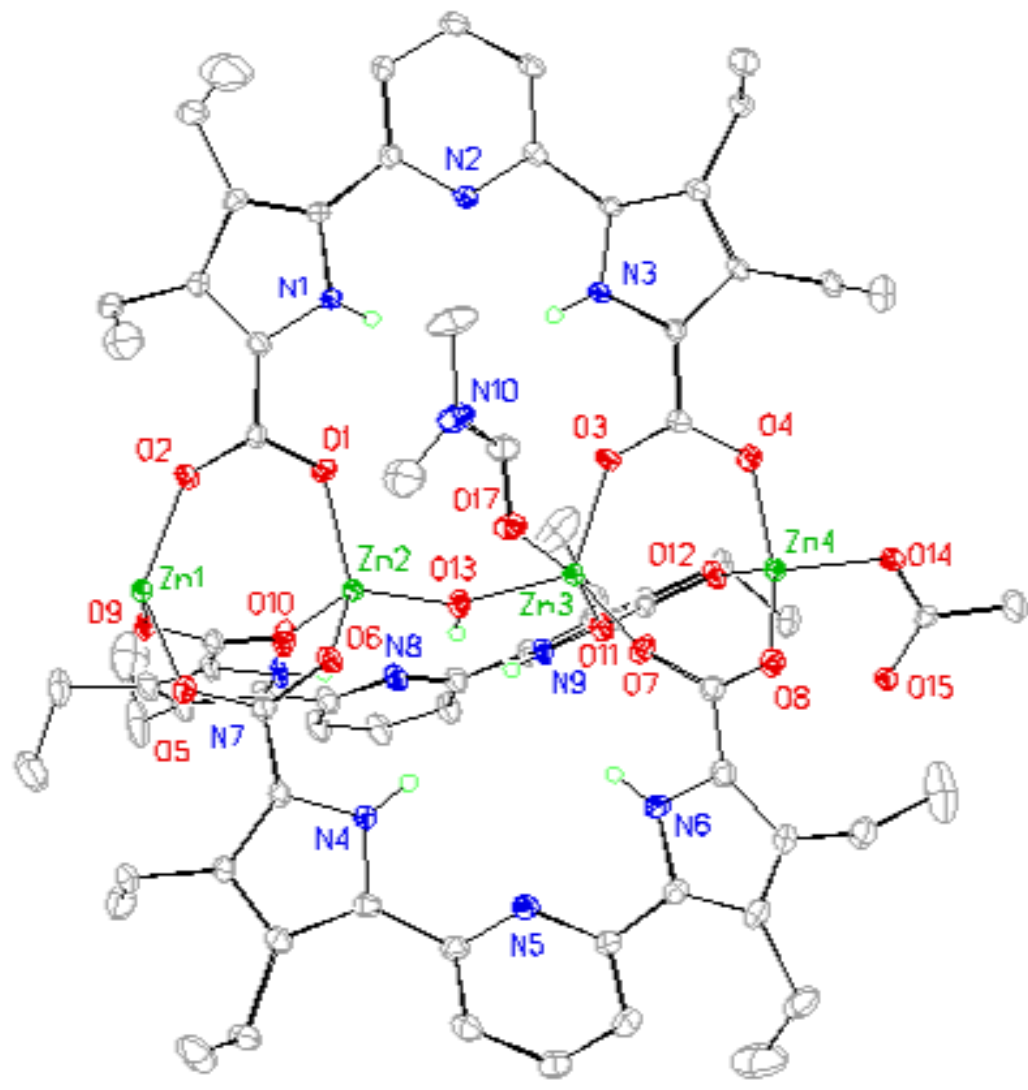

Figure S18. View of a portion of the polymeric Zn complex (cage-2) showing the heteroatom labeling scheme. Displacement ellipsoids are scaled to the 50\% probability level. Most $\mathrm{H}$ atoms have been omitted for clarity. 
Table S5 Crystal data and structure refinement for cage-2.

\begin{tabular}{|c|c|c|}
\hline Empirical formula & \multicolumn{2}{|c|}{$\mathrm{C}_{87.50} \mathrm{H}_{119.50} \mathrm{~N}_{14} \mathrm{O}_{21} \mathrm{Zn}_{4}$} \\
\hline Formula weight & \multicolumn{2}{|l|}{1964.94} \\
\hline Temperature & \multicolumn{2}{|l|}{$100(2) \mathrm{K}$} \\
\hline Wavelength & \multicolumn{2}{|l|}{$0.71073 \AA$} \\
\hline Crystal system & \multicolumn{2}{|l|}{ monoclinic } \\
\hline Space group & \multicolumn{2}{|l|}{$\mathrm{P} 21 / \mathrm{n}$} \\
\hline \multirow[t]{3}{*}{ Unit cell dimensions } & $\mathrm{a}=14.7663(12) \AA$ & $\alpha=90^{\circ}$ \\
\hline & $\mathrm{b}=26.944(2) \AA$ & $\beta=101.593(3)^{\circ}$. \\
\hline & $\mathrm{c}=24.182(2) \AA$ & $\gamma=90^{\circ}$ \\
\hline Volume & \multicolumn{2}{|l|}{$9424.9(13) \AA^{3}$} \\
\hline $\mathrm{Z}$ & \multicolumn{2}{|l|}{4} \\
\hline Density (calculated) & \multicolumn{2}{|l|}{$1.385 \mathrm{Mg} / \mathrm{m}^{3}$} \\
\hline Absorption coefficient & \multicolumn{2}{|l|}{$1.081 \mathrm{~mm}^{-1}$} \\
\hline $\mathrm{F}(000)$ & \multicolumn{2}{|l|}{4122} \\
\hline Crystal size & \multicolumn{2}{|c|}{$0.32 \times 0.16 \times 0.08 \mathrm{~mm}$} \\
\hline Theta range for data collection & \multicolumn{2}{|l|}{3.019 to $27.484^{\circ}$. } \\
\hline Index ranges & \multicolumn{2}{|c|}{$-17<=\mathrm{h}<=19,-34<=\mathrm{k}<=34,-31<=1<=31$} \\
\hline Reflections collected & \multicolumn{2}{|l|}{145206} \\
\hline Independent reflections & \multicolumn{2}{|c|}{$21571[\mathrm{R}(\mathrm{int})=0.0766]$} \\
\hline Completeness to theta $=25.242^{\circ}$ & \multicolumn{2}{|l|}{$99.8 \%$} \\
\hline Absorption correction & \multicolumn{2}{|c|}{ Semi-empirical from equivalents } \\
\hline Max. and min. transmission & \multicolumn{2}{|l|}{1.00 and 0.755} \\
\hline Refinement method & \multicolumn{2}{|c|}{ Full-matrix least-squares on $\mathrm{F}^{2}$} \\
\hline Data / restraints / parameters & \multicolumn{2}{|l|}{$21571 / 1008 / 1184$} \\
\hline Goodness-of-fit on $\mathrm{F}^{2}$ & \multicolumn{2}{|l|}{1.084} \\
\hline Final $R$ indices $[\mathrm{I}>2 \operatorname{sigma}(\mathrm{I})]$ & \multicolumn{2}{|c|}{$\mathrm{R} 1=0.0544, \mathrm{wR} 2=0.0936$} \\
\hline $\mathrm{R}$ indices (all data) & \multicolumn{2}{|c|}{$\mathrm{R} 1=0.0757, \mathrm{wR} 2=0.1000$} \\
\hline Extinction coefficient & \multicolumn{2}{|l|}{$\mathrm{n} / \mathrm{a}$} \\
\hline Largest diff. peak and hole & \multicolumn{2}{|c|}{0.578 and -0.536 e. $\AA^{-3}$} \\
\hline
\end{tabular}




\section{References}

(S1) Setsune, J.-i.; Toda, M.; Watanabe, K.; Panda, P. K.; T. Yoshida, Tetrahedron Lett. 2006, 47, 7541.

(S2) Zhang, Z.; Lim, J. M.; Ishida, M.; Roznyatovskiy, V. V.; Lynch, V. M.; Gong, H. Y.; Yang, X.; Kim, D.; Sessler, J. L. J. Am. Chem. Soc. 2012, 134, 4076.

(S3) CrystalClear 1.40 (2008). Rigaku Americas Corportion, The Woodlands, TX.

(S4) SIR2004. A program for crystal structure solution. Altomare, A.; Burla, M.C.; Caliandro, M.; Camalli, M.; Carrozzini, B.; Cascarano, G.L.; De Caro, L.; Giacovazzo, C.; Olidori, G.; Spagna, R. J. Appl. Cryst. 2005, 38, 381-388.

(S5) Sheldrick, G. M. (2015). SHELXL-2014/7. Program for the Refinement of Crystal Structures. A. L. Spek, Acta Cryst. 2015, C71, 9-18.

(S6) Spek, A. L. (1998). PLATON, A Multipurpose Crystallographic Tool. Utrecht University, The Netherlands.

(S7) WinGX 1.64. (1999). An Integrated System of Windows Programs for the Solution, Refinement and Analysis of Single Crystal X-ray Diffraction Data. L. J. J. Farrugia, Appl. Cryst. 1999, 32, 837-838.

(S8) $\mathrm{R}_{\mathrm{W}}\left(\mathrm{F}^{2}\right)=\left\{\Sigma \mathrm{w}\left(\left|\mathrm{F}_{\mathrm{O}}\right|^{2}-\left|\mathrm{F}_{\mathrm{c}}\right|^{2}\right)^{2} / \Sigma \mathrm{w}\left(\left|\mathrm{F}_{\mathrm{o}}\right|\right)^{4}\right\}^{1 / 2}$ where $\mathrm{w}$ is the weight given each reflection.

$\left.\mathrm{R}(\mathrm{F})=\Sigma\left(\left|\mathrm{F}_{\mathrm{O}}\right|-\left|\mathrm{F}_{\mathrm{C}}\right|\right) / \Sigma\left|\mathrm{F}_{\mathrm{O}}\right|\right\}$ for reflections with $\mathrm{F}_{\mathrm{O}}>4\left(\sigma\left(\mathrm{F}_{\mathrm{O}}\right)\right)$.

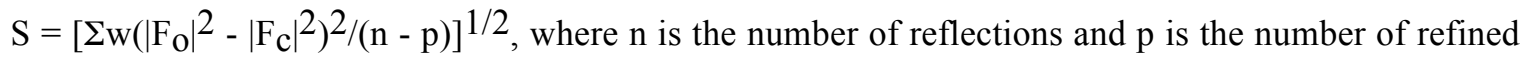
parameters.

(S9) International Tables for X-ray Crystallography (1992). Vol. C, Tables 4.2.6.8 and 6.1.1.4, A. J. C. Wilson, editor, Boston: Kluwer Academic Press.

(S10) Sheldrick, G. M. (1994). SHELXTL/PC (Version 5.03). Siemens Analytical X-ray Instruments, Inc., Madison, Wisconsin, USA. 